NBER WORKING PAPER SERIES

\title{
OCCUPY GOVERNMENT: \\ DEMOCRACY AND THE DYNAMICS OF PERSONNEL DECISIONS AND PUBLIC SECTOR PERFORMANCE
}

\author{
Klenio Barbosa \\ Fernando V. Ferreira \\ Working Paper 25501 \\ http://www.nber.org/papers/w25501 \\ NATIONAL BUREAU OF ECONOMIC RESEARCH \\ 1050 Massachusetts Avenue \\ Cambridge, MA 02138 \\ January 2019, Revised February 2021
}

This research project started in April 2016, and was first presented in November 2017. We are grateful to the comments of Santosh Anagol, Paulo Arvate, Audinga Baltrunaite, Jean Beuve, Felipe Campante, Nathan Canen, Emanuelle Colonnelli, Raphael Corbi, Jacques Cremer, George Deltas, Dakshina de Silva, Alessandra Fenizia, Claudio Ferraz, Thomas Fujiwara, Maria Guadalupe, Guo Xu, Lucas Novaes, Mounu Prem, Stéphane Saussier, Pedro Souza, Pablo Spiller, Bruno Rocha, Steve Tadelis, Edoardo Teso, Guo Xu, Leonard Wantchekon, and all participants at the National Tax Association meeting, Paris-Berkeley Workshop, Lancaster Conference on "Auctions, Competition, Regulation, and Public Policy," Kellogg-Northwestern "Urban Economics Conference: The Future of Cities," SEA meeting, Econometric Society World Congress, Urban Economics Association, and PUC-Rio seminars for very helpful comments. We thank the Research Sponsors of the Zell/Lurie Real Estate Center at Wharton for financial support, and Qize Chen, Anna Gao, Min Kim, Rafael Tavares, and Trevor Woolley for their outstanding research assistance. Klenio Barbosa gratefully acknowledges the São Paulo Research Foundation (FAPESP) for the travel grant (2018/05086-4). All errors are our responsibility. The views expressed herein are those of the authors and do not necessarily reflect the views of the National Bureau of Economic Research.

NBER working papers are circulated for discussion and comment purposes. They have not been peer-reviewed or been subject to the review by the NBER Board of Directors that accompanies official NBER publications.

(C) 2019 by Klenio Barbosa and Fernando V. Ferreira. All rights reserved. Short sections of text, not to exceed two paragraphs, may be quoted without explicit permission provided that full credit, including $\odot$ notice, is given to the source. 
Occupy Government: Democracy and the Dynamics of Personnel Decisions and Public Sector

Performance

Klenio Barbosa and Fernando V. Ferreira

NBER Working Paper No. 25501

January 2019, Revised February 2021

JEL No. D72,D73,H70,J45,M5

\section{ABSTRACT}

We study the causes and consequences of patronage in Brazilian cities since the country's redemocratization. Our data consist of the universe of local public sector employees merged with their party affiliations, and a dynamic regression discontinuity design is applied to deal with the endogeneity of patronage. Elections have consequences for patronage, with winning political coalitions increasing their shares of public sector workers and wages by 3-4 percentage points during a mayoral term, and also occupying civil servant jobs to perform key service-oriented tasks in education and public health. This type of patronage accounts for more than half of the dramatic increase in public sector political employment since the Brazilian re-democratization. The political occupation of government jobs is not associated with ideology, though. Instead, lack of accountability and rent-seeking are the primary driving forces, while reliance on intergovernmental transfers only increases patronage for smaller cities. Finally, we estimate the long-term consequences of this political occupation for fiscal outcomes conditions and for the quality of education and health care services. More political occupation does not affect the size of local governments, but it changes the composition of expenditures and public workers: the hiring of politically connected workers crowds out, practically one-to-one, non-affiliated teachers and doctors. The increased political occupation in Brazilian cities resulted in negative long term outcomes for local citizens in the form of less years of formal schooling and higher mortality rates.

Klenio Barbosa

SKEMA Business School

60, Rue Fedor Dostoievski

Sophia-Antipolis , 06902

France

klenio.barbosa@skema.edu

Fernando V. Ferreira

Wharton Real Estate

University of Pennsylvania

430 Vance Hall

3733 Spruce Street

Philadelphia, PA 19104-6301

and NBER

fferreir@wharton.upenn.edu

A data appendix is available at http://www.nber.org/data-appendix/w25501 


\section{Introduction}

Do local democratic elections influence city finances, the quality of local public goods, and long-term outcomes for citizens? The size and type of local public expenditures in the United States are not significantly impacted by electing a democrat or republican to the mayoral office (Ferreira and Gyourko, 2009), in part because of Tiebout (1956) sorting of voters. ${ }^{1}$ But in places with poor accountability and low quality of governance, political parties may use the government for their own benefit. This can take different forms, ranging from general corruption related to fraud in public procurements and diversion of funds (Ferraz and Finan, 2011) to the occupation of the governmental sector via a higher degree of patronage (Folke, Hirano, and Snyder, 2011; Xu, 2018) and public workers who receive a large wage premium relative to the private sector (Finan, Olken, and Pande, 2015). These practices can significantly affect government performance since cities generally spend a high share of resources with public sector personnel, and the type and quality of public employees may directly impact the deliverance of services, such as basic education and health care. ${ }^{2}$

In this paper, we study how democratic elections affect the employment of politically connected workers, the mechanisms behind those personnel decisions, and their ultimate consequences for public finances and for the performance of public education and health care services in Brazilian municipalities. We proceed in three steps: First, we estimate the extent of patronage practices in Brazilian cities, i.e., the hiring of civil servants politically connected with a winning political coalition, and how this occupation of local governments can have a lasting impact on the public sector personnel; Second, we investigate key mechanisms that may explain different levels of patronage observed in local governments - federal transfers, lack of accountability, party ideology, and rent seeking; Third, we show how the political occupation of local governments impact public expenditures and the quality of education and health care services.

Brazilian municipalities are the focus of our empirical work, where both personnel decisions and public expenditures have had striking patterns since the first presidential election with popular vote in 1990, after a 26-year military dictatorship. The government share of GDP in Brazil grew from $29 \%$ in the early 1990 s to more than $40 \%$ in the late 2000 s, with cities accounting for

\footnotetext{
${ }^{1}$ Hoteling (1929) and Downs (1957) argue that elections should not matter as long as politicians and their parties follow the wishes of the voters. However, political parties may matter at other levels of government (Besley and Case, 2003; Lee, Moretti, and Butler, 2004), and their influence could be the result of strategic extremism (Glaeser, Ponzetto, and Shapiro, 2005) or due to candidates that cannot credibly commit to moderation (Alesina, 1988; Besley and Coate, 1997).

${ }^{2}$ In general, governments responsible for labor-intensive services, such as education, health, safety, and city maintenance, will have the largest fraction of expenditures assigned to personnel. U.S. school districts, for example, spend more than $80 \%$ of current expenditures on wages and benefits.
} 
approximately half of the public sector. City expenditures on personnel almost doubled over the last two decades, increasing from 35\% of local budgets in 1995 to almost 50\% in 2013, the last year of our sample. The share of local labor force employed by city governments reached almost $10 \%$ in 2010 , representing about $40 \%$ of all legally registered employees in the average Brazilian city. ${ }^{3}$ At the same time, Brazilian's perceptions of the quality of public services, measured by the World Bank government effectiveness index, has dropped from 0.09 points in 2000 to -0.09 points in $2013 .{ }^{4}$

In order to identify the connections of each public worker with the political coalition in power, we access an annual individual-level dataset with the universe of public employees, including their names, wages, labor contract, and occupation, for almost all Brazilian municipalities from 1995 to $2013 .^{5}$ We then merge these microdata with the universe of individuals affiliated with political parties in Brazil. Approximately $10 \%$ of the adult population in Brazil was associated with a political party in 2013 , a share that has grown steadily since the re-democratization. We restrict our analysis to the civil servants which are permanent public employees and account for about 85 $\%$ of all local public workers. By focusing on civil servants we center our investigation on the effect on personal decisions of front end public employees, such as teachers and doctors, thereby insulating our analysis from the known political appointees turnover in the public sector due to elections (Boyne et al. 2010; Dull et al. 2012). With the merged data in hand, we show in Figure 1 that the share of civil servants affiliated with a political party increased from $16 \%$ in 1995 to more than $30 \%$ since 2013. Moreover, Figure 2 presents a map with the distribution of those shares in 1995 and 2013 by city, holding constant the 1995 quintile thresholds. The increase in share of affiliated workers was widespread across the country, and not just concentrated in a few cities or regions.

While shocking, this large increase in the share of public workers with political affiliation may not necessarily correspond to an increase in patronage. Political parties commanding a city are generally stronger electorally, and likely to have more sympathizers and affiliates, including public employees. In order to deal with the endogeneity, we compare the public employment of

\footnotetext{
${ }^{3}$ A large fraction of private sector employment are still conducted under informal labor agreements. These data are from the Brazilian Institute of Geography and Statistics (IBGE) and from the Brazilian National Treasury Secretariat (STN).

${ }^{4}$ Government effectiveness index captures perceptions of the quality of public services, the quality of the civil service and the degree of its independence from political pressures, the quality of policy formulation and implementation, and the credibility of the government's commitment to such policies. These data are from World Bank's worldwide governance indicators (wgi) survey.

${ }^{5}$ Our data set is based on RAIS (Relação Annual de Informações Sociais), a mandatory database assembled and managed by the Brazilian Ministry of Labor, and contains information for more than $95 \%$ of all cities in Brazil. Details of the microdata are presented in Section 3.
} 
political coalitions that barely won an election with the same outcome of coalitions that barely lost - in practice comparing political coalitions with similar unobserved political power. Using five four-year municipal electoral cycles, from 1996 to 2012, including data from all party coalitions formed in each election, we show that this regression discontinuity design (Lee, 2008) produces levels and trends of political public employment that are similar for winning and losing coalitions in the years prior to an election.

Another challenge to identification is the dynamics of several election cycles. For example, winning (losing) by a narrow margin of victory may also increase (decrease) the probability of reelection, and therefore affect the probability of "treatment" in the next election. Moreover, political coalitions in Brazil are fluid, with several changes in each city during the five election cycles. We deal with these potential changes in treatment status by implementing a dynamic regression discontinuity design developed by Cellini, Ferreira, and Rothstein (2010). We adapt this approach to our setting in order to estimate the short and long-term impact of electing a mayor from a given coalition under dynamic treatment assignments. These are "treatment-on-the-treated" effects that, in practice, hold constant all past election-coalition outcomes in a city. We also estimate separate effects for leading and supporting parties, a critical step given that political coalitions in Brazil have more than three supporting parties, on average.

We apply our dynamic estimator using the most comprehensive dataset of local elections, public employees, party affiliations, and public finances assembled to date. We find that the share of city wages devoted to civil servants allocated to a winning political coalition increases by 2.5 percentage points in the first year of a mayoral term, and then reaches almost 4 percentage points prior to the next election cycle. The actual share of city employees of the winning coalition increase by only 3 percentage points in a mayoral term, indicating that the positions filled by party loyalists offer higher compensation. Two-thirds of the political gains in employment and wages are concentrated in the party that leads a coalition, while one-third goes to supporting parties. As civil servants are tenured positions, they are more likely to stay in government for longer than one mayoral term - we find that such occupation of local governmental jobs last more than a decade, thereby having long-lasting effects on local public personnel.

The dynamic of public sector occupation varies over the course of a mayoral term. Hiring party members who were already affiliated before the election accounts for the majority of the first year effect. But by the third year of a mayoral term, two other categories gain relevance in the occupation of public sector jobs: newly affiliated party members (affiliated after the election) and old public employees who decide to join the winning parties. These new and old employees 
affiliated after elections account for 30 percent of the total occupation effect in the third year of a mayoral term.

What are the mechanisms behind the increasing capture of the public sector employment by political parties? We investigate three potential channels related to i) Fiscal rules in the form of intergovernmental transfers; ii) Lack of accountability proxied by audits, media presence, and city size; and iii) Political economy factors represented by ideology and rent-seeking.

Federal and state transfers are the main sources of funding for Brazilian municipalities (85 percent), and local taxes (property and service taxes, building permits fees) only represent 6 percent of the budget. These soft budget constraints created by excessive transfers may potentially lead to corruption and misuse of funds (Fisman and Gatti, 2002). We use a research design based on discontinuous changes in federal transfers (FPM) to municipalities at given population thresholds to causally estimate how patronage varies with intergovernmental transfers. Municipalities that belong to a particular population bracket receive the same amount of federal and state transfers in a given year, whereas municipalities slightly above (below) the upper (lower) bound of each bracket receive, on average, 20 percent more (less) revenue. We find that FPM transfers do increase the share of total wages assigned to employees affiliated to elected parties. The patronage effect is particularly large for small cities (with population around 10,000), for which FPM transfers correspond to a large fraction of municipal revenues.

Next, we examine whether accountability and the quality of governance can limit the occupation of the public sector by winning parties. There are a number of anecdotal evidence showing that cities in Brazil rig local recruitment processes in order to favor politically connected individuals. ${ }^{6}$ Empirically we find that the capture of the public sector by political parties is larger in smaller (and less developed) cities that lack accountability. In addition, the presence of local media (radio, newspapers, magazines, TV and internet) limits patronage practices in public sector personnel decisions. Finally, we find that random government audits of public resources (as in Ferraz and Finan, 2008, 2011; in Brollo, Nannicini, Perotti and Tabellini, 2013; in Avis, Ferraz and Finan, 2018; and in Chu et al., 2020) reduce future patronage practices. All these proxies for accountability point in the same direction and may explain why municipal voters have little hope to punish politicians that adopt such hiring practices.

\footnotetext{
${ }^{6}$ A series of frauds involving civil service exam leaks to individuals politically aligned to the city mayors are under investigation by the Brazilian Public Prosecution Offices (Ministério Público). For instance, the 2019 prosecutor's investigation named Apaniguados has found proofs (intercept phone calls, testimonies, etc.) that the mayors of some Brazilian cities were fraudulently allocating civil service jobs to political allies. The mayors involved in that scheme were arrested by the Brazilian Federal Police (MPSP, 2019).
} 
We then analyze the political economy channels by testing if party ideology is responsible for the expansion of public sector's political employment. For instance, one might expect left leaning governments to allocate a larger share of expenditures on personnel given that the leftist parties are known for defending a larger size of government -the most notable example being the Communist Party of China. There is a fair amount of heterogeneity in the dynamic treatment effect of winning an election, with some leading parties gaining more than 4 percentage points in wage shares during a mayoral term, while others barely gaining 1 percent. But such variation is not correlated with the ideology index developed by Power and Zucco (2009, 2012, 2019), which classifies Brazilian parties according to a left-centrist-right leaning scale. Instead, three of the largest patronage parties are PMDB (center), PP (right), and PT (left) which also happen to be the parties implicated in the recent corruption scandal involving the largest Brazilian company, Petrobras, ultimately leading to the impeachment of former president Dilma Rousseff in 2015. We do, however, find another important source of heterogeneity: the patronage effect is larger for bigger parties, i.e., with a larger share of local party members. This indicates that the country's low quality governance system is exploited by all parties, in a rent-seeking competition where bigger parties have more people demanding and being rewarded with jobs in the public sector.

What are the long-term consequences of this political occupation of civil servant positions? First, more patronage could change the composition of local expenditures since the hiring of politically connected workers to conduct administrative activities could lead to a reduction in resources to hire more qualified workers, such as teachers and doctors. That in turn would lead to a reduction in the quality of local public services since those employees are critical inputs for quality of education (Glewwe and Kremer, 2006) and health care (Das, Hammer and Leonard, 2008). Second, even among the set of teachers and doctors, patronage could lead to the hiring of connected workers. Those politically connected teachers and doctors could result in lower quality of public services for two reasons: a) They may have lower unobserved quality and were only hired because of political connections; b) Political connected workers may be more likely to shirk and avoid forfeits , and may behave as "ghost workers" - absenting from work at no penalty. ${ }^{7}$

We test those consequences by modelling differences in long term outcomes for each city as a function of long term changes in the political occupation of civil servant jobs, i.e., the public sector wage share devoted to affiliated personnel. Given the endogeneity of political occupation,

\footnotetext{
${ }^{7}$ Ghost workers are a well-known feature of the Brazilian public sector. For example, the Brazilian Federal police and the Brazil's controller's office (CGU, Controladoria Geral da Uniao) found out that a large share of doctors receive wages from the public sector but spend most of the work day attending patients in their own private clinics (CGU, 2015).
} 
we instrument it with an exogenous city level patronage index based on the estimates from our dynamic RD framework.

We find that political occupation does not have a long term effect on the size of local governments, which is not a surprise given that Brazilian cities receive the majority of their revenues from state and federal governments. However, there are large effects on the composition of expenditures: Each percentage point increase in political occupation raises the share of city expenditures with affiliated civil servants by 0.33 percentage points, and also decreases the expenditures with non-affiliated employees by a similar amount, in practically a one-to-one crowd out. Moreover, cities with more political occupation have smaller shares of city resources devoted to teachers and doctors. Interestingly, we also find that such reduction mostly affects non-affiliated employees, which in practice means that a disproportional share of politically connected teachers and doctors occupy those careers.

These observed changes in the quality of education and health inputs do indeed impact long term outcomes, as we find significant negative consequences for cities with larger political occupation of civil service positions. A one-standard deviation increase in the patronage index (which is 8.93) leads to a reduction in 1.39 percentage points in the share of local citizens with 11 or more years of education. This is a non-negligible set back given that the share of individuals with more than 11 years of education increased by 20 percentage points in the same period, mainly due to significant efforts by the federal government to improve education attainment in Brazil (Ferreira, Bourguignon and Leite, 2003; Glewwe and Kassouf, 2012; Silveira at al., 2017). Moreover, a one standard deviation increase in patronage index leads to a raise in mortality of 3.84 children under age 4 per 100,000 over 1996-2013, which corresponds to 15 percent of the impact of almost a decade of a successful public health care program in Brazil (Rocha and Soares, 2010).

Related Literature. In addition to the public economics, political science, and development literatures described above, our work is also related to the literature on how democratic institutions shape governments and policy. Aidt and Jensen (2013) show that franchise extension can increase the size of government, while Fujiwara (2015) shows that improving the political participation of less educated voters can advance policies that benefit them. Acemoglu, Naidu, Restrepo, and Robinson (2015) found a dynamic impact of democracy on tax revenues as a fraction of GDP, potentially leading to fiscal redistribution as well. Our results empirically corroborate these views, although our mechanisms are related to rent-seeking and lack of accountability. 
Our paper also relates to the literature on personal benefits of political connections. While we show that individuals affiliated with a party benefit from winning an election, recent papers have examined the wealth accumulation of politicians. Using an RD design, Eggers and Hainmueller (2009) find that British Conservative Party members of Parliament (MPs) benefit financially from public office while Labour MPs do not. Querubin and Snyder (2009) examine the wealth accumulation of US politicians during 1850-80 using a RD design and find that election winners outearn losers only from 1870 to 1880. Fisman, Schulz and Vig (2014) show a much higher rate of wealth accumulation of state politicians in India. Gagliarducci and Manacorda (2020) find that family connections to politicians helps individuals to get a job in the private sector. Recently, Jiang and Zhang (2020) show that provincial leaders allocate significantly more transfers to localities governed by officials who are part of their networks.

A recent set of papers study the personnel economics of the state. These papers look, among other things, at how public servants' behavior maps into the performance of public services and how internal policies may be framed to make the best of the conflicting interests faced by officials (Finan, Olken and Pande, 2015; Cameron, de Figueiredo and Lewis, 2016). For instance, Akhtari, Moreira and Trucco (2020) explore how political turnover in Brazil impacts the replacement rate of headmasters and teachers in schools controlled by the municipality, thereby negatively impacting the public education provision. Other recent papers study the selection of public servants and how political connections shape public personnel decisions (Dal Bó et al., 2017; Dal Bó, Finan, and Rossi, 2013; Deserrano, 2019; Weaver, 2018; Fang et al., 2018).

Two recent papers about patronage in Brazil are closely related to our independently developed research. Colonnelli, Prem and Teso (2020) conduct a groundbreaking investigation of the causal effect of becoming a campaign donor and/or running as a candidate for city councilor, on the probability of obtaining a public-sector job, while Brollo, Forquesato and Gozzi (2017) estimate the effect of being the party in power on the employment of party members in the public sector. Our paper advances the research above in four important ways: 1) We have a more complete longitudinal data on the universe of Brazilian public sector employees and party affiliates over the 1995-2013 period; 2) We employ a causal dynamic treatment effects model that accounts for multiple waves of mayoral elections and party coalitions; 3) We examine multiple mechanisms that explain the variation in patronage across Brazilian cities; and 4) More importantly, we estimate the long term consequences of patronage in Brazilian cities, especially how the political occupation of civil service positions affect inputs to education and health services, and the performance of the local public sector, both from public finance and public service provision perspectives. 
The rest of the paper proceeds as follows: Section 2 describes the Brazilian institutions, Section 3 discusses our empirical methods, and Section 4 describes our database. In Section 5 we present our results, in Section 6 the potential mechanisms, and in Section 7 the consequences for public expenditures, education and health outcomes. Section 8 concludes.

\section{Brazilian Institutions}

Brazil is a federal republic with a presidential system organized in three levels: federal, state and municipal. There are more than 5,500 municipalities as of 2015, and each has an executive and legislative branch. The mayor is the head of the executive branch of the municipality, and each city also has a city council. ${ }^{8}$ Municipalities are generally responsible for managing and delivering a large range of public goods and services to their citizens, such as child care, early childhood and primary education, basic health services, local public transportation, local traffic safety, recreational facilities, water supply and sanitation. ${ }^{9}$

Each city has its own budget and the freedom to implement its own public policies and to make spending choices. Funding for the services and goods provided by municipalities comes from local taxes (e.g., property and service taxes, building permits fees), and from state and federal transfers (whose main source of revenues are sales taxes and income taxes, respectively). Transfers are the main source of funding for municipalities, accounting for 85 percent of the municipality revenue on average. A major role is played by the federal fiscal transfer scheme called Fundo de Participação dos Municípios (FPM). FPM is the largest program of transfers to municipalities, accounting for almost 80 percent of all types of federal transfers and for 31 percent of municipal revenues. $^{10}$

\subsection{Public Sector Careers}

Municipalities in Brazil independently create, manage and modify public sector careers. Each municipality has its own plan for positions, careers and wages, which establishes tasks, functions and required qualifications for every position in the municipal bureaucracy.

\footnotetext{
${ }^{8}$ The number of seats in each city council depends on the municipality population size. Council members are responsible for making local laws, overseeing the corresponding executive branch, and proposing and approving the annual budget.

${ }^{9}$ States, on the other hand, are mainly responsible for secondary education, general safety (police and firefighters), non-basic health services, and any infrastructure project that involves multiple municipalities.

${ }^{10}$ The ICMS-Parcel, is another important transfer that corresponds to 15 percent of the municipal budget, and is based on a fraction of the state sponsored value-added tax raised within the municipality. Lastly, the FUNDEF/FUNDEB is special federal fund for expenditures in education and accounts for 10 percent of municipal revenues. It is a nondiscretionary fund for daily operations of municipal public schools.
} 
Municipalities are also responsible for the selection and hiring of municipal workers. Those workers mainly fall into three categories: civil servants, political appointees, and temporary workers.

The largest category of public sector jobs is civil service, accounting for about $85 \%$ of all public workers in Brazilian municipalities. The Brazilian constitution establishes that municipalities have to rely on transparent rules and requirements for the selection of civil servant public works, and that each city is responsible for the details of the implementation of those rules. In theory, each job applicant is to present academic and professional credentials and undertake a formal civil service examination, which is job-specific and consists of a combination of written and oral tests. Civil servants acquire tenure after three years of service, following which they can be fired only for reasons of misconduct after a judicial decision. Although legislation has determined that the recruitment and selection process for civil service positions should be based on candidates' merits and professional capabilities, the effective criteria for hiring civil servants are established according to local needs. This affords city mayors a margin of discretion that can potentially allow them to favor members of their parties when selecting new hires. In fact, newspaper articles often report scandals of manipulation and fraud in civil service examinations in Brazilian municipalities that aimed to favor the hiring of a certain group of candidates. ${ }^{11}$

The hiring of political appointees is limited to positions of high-level public officials (including directors, managers, supervisors, and advisors). Federal legislation gives discretion to politicians to select people for these leadership roles. ${ }^{12}$ Finally, temporary public servants are hired to meet temporary and exceptional needs of public administrations, defined by politicians or highlevel public officials. In such cases, no civil service exam is required and the selection process can be based on the analysis of applicants' curriculum, without other formal objective criteria.

There are many advantages of holding a public sector job in Brazil, such as the fact that government positions are formal and guarantee many benefits such as (at least) 13 monthly wages, one-month of paid vacation, a special retirement plan, and lower work load among others.

We center our analysis on the civil servants. They are mainly front-end workers in the provision of local public services, as education and basic health care. They occupy key serviceoriented positions as teachers, doctors, public health professionals, and school staff among others. By restricting our analysis to civil servants we focus on the effect of an election on personal

\footnotetext{
${ }^{11}$ For instance, UOL, the largest Brazilian news portal, has reported that the Brazilian Public Prosecution Offices (Ministério Público) have been investigating frauds in local civil service examinations. Prosecutors investigations have found hard evidence of leaks of civil service exam to individuals politically aligned to the city mayors.

${ }^{12}$ Regular civil servants can also be promoted to positions of trust which are high-level public posts with similar status, earning and power of appointee positions.
} 
decisions of public employees who are more likely to work on the front lines of the delivery of local public services.

\subsection{Political Parties and Party Affiliation}

Brazil has a multiparty political system, composed of 35 officially registered national parties as of 2015. According to TSE, 12 million Brazilians were affiliated with political parties in 2015, which corresponds to 6 percent of the Brazilian population. Parties need affiliates to be legally recognized and to provide support to their candidates in the elections. For instance, the Brazilian electoral legislation establishes that a party must have a minimum number of members, which corresponds to $0.5 \%$ of the votes casts in the previous National Election, homogenously distributed across the 26 Brazilian states.

Based on shares of total affiliates, the most important parties are the Workers' Party (PT), the Brazilian Democratic Movement Party (PMDB), the Brazilian Social Democratic Party (PSDB), and Democrat Party (DEM). ${ }^{13}$ Other medium sized parties, like the Republican Party (PR) and the Progressive Party (PP), play significant roles in the National Congress; and others, like the Brazilian Socialist Party (PSB) and the Democratic Labor Party (PDT), have political power in strategic states.

In terms of ideology, political scientists categorize parties in Brazil in a wide range. Coppedge (1997), based on the perception of experts, classifies PT and PSB as left-wing, the PSBD and PDT as center-left, PMDB as center, PP as center-right, and PR and DEM as right-wing. Power and Zucco $(2009,2012,2019)$ develop an alternative measure of party ideological position based on survey responses of federal legislators from 1990 to 2017. By this measure, there is a great dispersion across Brazilian party ideology.

All eligible voters can affiliate with a political party at any point in time. ${ }^{14}$ As opposed to the United States, affiliation is not determined during voting registration. Every political party has its own membership rules. Some impose registration fees and a selection process that may involve interviews and formal examinations, while others parties, especially more recently, just require an online registration. The rights and duties of affiliates are described in the statute of the party.

\footnotetext{
13 They are also the parties with the longest tradition in the country, having elected numerous and important legislators, senators and governors since the Brazilian re-democratization. PSDB won the presidency in 1994 and 1998 , in a coalition in which DEM assigned the vice-president. PT was the leading party of a coalition that governed the country from 2002 until the recent impeachment of President Rousseff in 2016. PMDB occupied the vice-presidency from 2006 to 2016, and then occupied the presidency after the impeachment.

14 The electoral legislation requires all parties to submit twice a year (April and October) an up to date list all of their members to the Superior Electoral Court (TSE). Superior Electoral Court (TSE) actively tracks party affiliation of all voters, cancelling the oldest membership if a voter is affiliated with more than one party.
} 
Parties may request financial contribution from their members for internal party maintenance, provide support to party candidates in electoral campaigns, and physical presence in certain party activities. Affiliates can also vote to choose the official candidate in the upcoming elections. However, internal decisions tend to be centralized in the directories, since voting power, in general, is not the same for all members.

\subsection{Municipal Elections, Candidates, and Coalitions}

Municipal elections for mayors and municipal councilors happen every four years midway between the national and state level elections. Those elections take place in October, and the winner candidates take office in January of the following year to serve a four-year term. In municipalities with less than 200,000 registered voters, mayors are elected by a simple majority rule in a singleround election. In the other municipalities, mayors are elected by a simple and popular majority vote in a two-round system. Since 1998 mayors can be elected for no more than two consecutive terms; before that reelection was not allowed.

Every political candidate must be a member of a legal party in order to run for public office. The electoral rules establish that a candidate must be affiliated with a political party at least six months before the election. As municipal elections are the first electoral races for the vast majority of individuals running for a public office, a new wave of affiliates happens in the municipal elections years.

But given that all political parties are relatively small, candidates heavily rely on political alliances in order to increase their electoral chances. Political coalitions are legally and independently formed a few months before each election in each city. These political coalitions provide many benefits to a candidate during the electoral campaign, such as the backing of a larger number of sympathizers and donors, and more public resources for the electoral campaign in the form of free radio and TV air time. ${ }^{15}$ They also may help the elected candidates during the mayoral term, although at that point political parties are free to change their alliances.

\section{Empirical Framework}

\footnotetext{
15 Brazilian electoral legislation establishes that during the 45 days prior of the municipal elections, parties are authorized to broadcast political agenda of their mayor and municipal councilor candidates on the radio and on the television. All parties together are entitled to 70 minutes a day in insertions. 90 percent of that time is distributed in proportion to the number of representatives that the parties have in the Federal Congress. The remaining 10 percent is distributed equally. In case there is an alliance between parties in the majority elections, it will be considered the sum of the federal deputies affiliated to the six largest parties of the coalition. In the case of coalitions for proportional (council) elections, the radio and TV time will be the result of the sum of the number of representatives of all parties.
} 
Suppose that a political party $p$ runs for the mayoral office in city $c$ and receives vote share $v_{p c}$. Let $b_{p c}=1\left(v_{p c}>v_{p \prime c}\right)$ be an indicator for the party receiving more votes than any of the other parties running for office, and therefore winning the election. Initially ignoring the dynamics of multiple election cycles and the possibility of forming coalitions, we can write a short-term outcome $y_{p c}$ (wages received by local public employees that belong to a political party, for example) as:

$$
y_{p c}=b_{p c} \theta+u_{p c}
$$

where $\theta$ is the causal effect of winning an election and $u_{p c}$ represents all other determinants of $y_{p c}$. However, winning an election may be correlated with other characteristics that influence outcomes, so $E\left[u_{p c} b_{p c}\right] \neq 0$. In our case, an important unobserved determinant of outcomes is the political power of certain parties and coalitions. The standard regression discontinuity strategy to deal with this issue, as pointed out by Lee (2008), is that as long as there is some unpredictable random component of the vote, a narrowly-decided election approximates a randomized experiment. The causal effect of winning an election can be identified by comparing personnel outcomes for parties that barely won an election (the "treatment group") with other parties that barely lost (the "control group"). ${ }^{16}$ Assuming that $E\left[u_{p c} \mid v_{p c}\right]$, the conditional expectation of the unobserved determinants of $y$ given the realized vote share, is continuous, we can approximate it by a polynomial function of order $g$ with coefficients $\gamma_{u}, F_{g}\left(v_{p c}, \gamma_{u}\right)$. Under this assumption we can rewrite (1) as:

$$
y_{p c}=b_{p c} \theta+F_{g}\left(v_{p c}, \gamma_{u}\right)+\varepsilon_{p c}
$$

where $\varepsilon_{p c}$ is asymptotically uncorrelated with $v_{p c}$ (and therefore with $b_{p c}$ ), and a regression of realized outcomes on the winning indicator, controlling for a flexible polynomial in the vote share, thus consistently estimates $\theta$.

We now extend the setup to allow for multiple elections in the same city, closely following the dynamic regression discontinuity framework developed in Cellini, Ferreira, and Rothstein (2010). Redefine $b_{p c t}$ to equal one if party $p$ in city $c$ wins the election and holds the mayoral office during the calendar years $t$ associated with a mayoral term, and zero otherwise (i.e., if the

\footnotetext{
${ }^{16}$ We include all parties in our estimates, as there is a large number of third and fourth place candidates with meaningful vote shares. See Anagol and Fujiwara (2016) for the importance of the runner-up effect. Our online appendix shows the histogram for each vote share for the $1^{\text {st }}, 2^{\text {nd }}$, and $3^{\text {rd }}$ place candidates.
} 
party did not run for mayor in that electoral cycle or if the party ran and lost the election). We can then write outcomes in any year $t$ as a function of the full history of mayoral elections in a city:

$$
y_{p c t}=\sum_{\tau=1}^{\tau=\bar{\tau}} b_{p c, t-\tau} \theta_{\tau}+u_{p c t}
$$

which estimates the causal effect of winning an election in $t-\tau$ on outcomes in year $t$, with $\bar{\tau}$ as the maximum number of relative years since an election allowed by the data. The causal parameter $\theta_{\tau}$ is commonly known as the effect of the "treatment on the treated", or TOT, since equation (3) explicitly controls for all other election outcomes. An OLS estimate of (3) would yield biased estimates of the TOT effects, so we again appeal to the assumption that winning an election is as good as randomly assigned conditional on a smooth function of the measured vote share. To bring the RD methodology to the "structural" equation (3), we augment each of the lagged election outcome indicators $b_{p c, t-\tau}$ and a polynomial in the vote share, $F_{g}\left(v_{p c, t-\tau}, \gamma_{\tau}\right)$. Both the $b_{p c, t-\tau}$ coefficient and the polynomial coefficients are allowed to vary freely with $\tau$, where $\tau$ is number of years after and election (for $\tau>0$ ). ${ }^{17}$ We also add fixed effects for each party, city, and calendar year, such that we can write (3) as follows:

$$
y_{p c t}=\sum_{\tau=1}^{\tau=\bar{\tau}}\left[b_{p c, t-\tau} \theta_{\tau}+F_{g}\left(v_{p c, t-\tau}, \gamma_{\tau}\right)\right]+\pi_{p}+\kappa_{c}+\lambda_{t}+\varepsilon_{p c t} .
$$

With the inclusion of controls for the election and vote share history in (3), the $\theta_{\tau}$ coefficients are identified from the contrast between parties in cities where an election in $t-\tau$ was narrowly won and those where the election was narrowly lost but the sequence of prior and subsequent elections and votes is similar. This has the advantage, for example, of not confounding the effects of winning an election with winning or losing other election cycles, which is key to understanding the long-term impact of party control on city personnel decisions.

So far, we have ignored the possibility of forming coalitions across parties in order to run for the mayoral office, which is a common feature of the Brazilian political system. In order to capture the impact coalitions we first assign vote shares to all parties in a coalition. Precisely, we replace $b_{p c, t-\tau}$ in equation (4) for two other dummies $b_{p c, t-\tau}^{l}$ and $b_{p c, t-\tau}^{s}$, which are, respectively, indicators for whether the party is a leading or supporting party of a winning candidate. Second, we add two other terms to equation (4), $l_{p c, t-\tau}$ and $s_{p c, t-\tau}$, which are dummies that represent,

\footnotetext{
${ }^{17}$ We also run some specifications that allow for $\tau \leq 0$ in order to test for pre-trends.
} 
respectively, the parties are leading or supporting parties of mayoral candidate. Our final estimating equation becomes:

$$
\begin{gathered}
y_{p c t}=\sum_{\tau=1}^{\tau=\bar{\tau}}\left[b_{p c, t-\tau}^{l} \theta_{\tau}+b_{p c, t-\tau}^{s} \varphi_{\tau}+l_{p c, t-\tau} \alpha_{\tau}+s_{p c, t-\tau} \beta_{\tau}+F_{g}\left(v_{p c, t-\tau}, \gamma_{\tau}\right)+\right. \\
\left.+l_{p c, t-\tau} F_{g}\left(v_{p c, t-\tau}, \delta_{\tau}\right)\right]+\pi_{p}+\kappa_{c}+\lambda_{t}+\varepsilon_{p c t} .
\end{gathered}
$$

We estimate this equation using a conventional panel of outcomes by party and city over calendar years. Standard errors are clustered by city. We label $\theta_{\tau}$ and $\varphi_{\tau}$ the patronage effects from leading and supporting parties of the winning coalitions.

A caveat with the empirical model above is that $\theta_{\tau}$ and $\varphi_{\tau}$ could be overestimated because of a mechanical effect in which the losing party leaves office (giving up the leadership of the main departments, for example) and the new party in power just replaces the main leadership positions. We first deal with this issue by exploiting our microdata: we know whether an employee is a political appointee in a leadership position or if the employee is a civil servant providing a direct service to the population. By only focusing on civil servants we can restrict the analysis to positions that suffer less from the mechanical effect. Second, we decompose the total effect into employees that were employed (or not) by the city in the year prior to the election, as that allows us to compare how much of the total effect is due to replacement of old positions v s new hires. Additionally, we interact those dummies with a dummy for belonging to a party in the year prior to the election. This interaction aims to decompose the effects and to capture other potential mechanisms, such as employees switching parties or becoming affiliated for the first time because of an election outcome.

Equation 5 assumes that all winning parties behave similarly once in power. If there is heterogeneity in $\theta$ across parties, our estimator identifies the average of $\theta_{p}$ among parties with close elections (Imbens and Angrist, 1994). But we can further interact $b_{p c, t-\tau}^{l}, b_{p c, t-\tau}^{s}$, $l_{p c, t-\tau}$ and $s_{p c, t-\tau}$ with dummies for each of the Brazilian parties, in order to test if parties adopt different personnel decisions while in office. We also interact the variables $b_{p c, t-\tau}^{l}, b_{p c, t-\tau}^{s}$, $l_{p c, t-\tau}$ and $s_{p c, t-\tau}$ with measures of federal transfer, city size, accountability, party size, and party ideology in order to understand some of the mechanisms driving the patronage effects. 
Finally, we also estimate a specific $\theta_{3}$ for each city in the country, by interacting a complete set of city indicators with the terms $b_{p c, t-3}^{l}$ and $b_{p c, t-3}^{s} \cdot{ }^{18}$ In section 7 we will use this parameter estimates as a city-level index in order to understand the long term consequences of the political occupation of civil service positions on education and health outcomes.

\section{Data}

\subsection{Public Employees}

We use a comprehensive longitudinal matched employer-employee administrative data set which takes the form of an annual census of all formal workers in Brazil (Menezes-Filho et al., 2008). RAIS (Relação Annual de Informações Sociais) is a mandatory database assembled and managed by the Brazilian Ministry of Labor every year since 1976. It includes individual information on earnings, occupations and other aspects of the job (tenure, weekly working hours, features of the employment contract), current and past employers, along with their identification numbers, locations and industries. It is widely recognized as a high-quality Census of the Brazilian formal labor market (Dix-Carneiro, 2014; Dix-Carneiro and Kovak, 2017). ${ }^{19}$ Apart from the informal sector workers, RAIS covers almost all public and private sector jobs, except for very few categories of workers (a subset of self-employed individuals and elected politicians) which are not required to report information to the Ministry of Labor. ${ }^{20}$

The data consist of job entries identified by worker identification number (PIS), worker full name, and firm-plant taxpayer identification number (CNPJ). These identifiers are unique and do not change over time. This allows us to track individual over time and across formal employers. Additionally, RAIS comprises a set of variables which are particularly important for our investigation: individual specific data on occupation and employment contract details. In RAIS, every worker is assigned an occupation specific to his/her current performing job, which is categorized according to the $\mathrm{CBO}$ (Classificação Brasileira de Ocupações). Based on the

\footnotetext{
${ }^{18}$ The parameter $\theta_{3}$ refers to the effect of the leading party election on political public employment in the third year after the election. It accounts for the leading party's patronage effect in one of the last years of the term and also the peak effect (as we show in Section 5).

${ }^{19}$ RAIS is the main tool used by the government to enable the payment of the "abono salarial" to eligible workers. "Abono salarial" is a government program that pays one additional minimum wage at the end of the year to workers whose average monthly wage was below two times the minimum wage, and whose job information was correctly declared in RAIS - among other minor requirements. For this reason, workers have an incentive to be counted in RAIS since they want to be eligible to receive the government benefits they are entitled. Given that employers (private and public organizations) are subject to severe fines if they do not regularly submit to the Ministry of Labor the information about their workers, employers also have incentives to precisely provide workers information in RAIS.

${ }^{20}$ Because RAIS is a census of the Brazilian formal labor market only, we cannot follow individuals that always have been working for the informal sector. We also lose track of workers who do not hold a job in the formal sector in a given year, but we can keep tracking them once they return to a job in the formal sector.
} 
performing job of each public employee, we can establish if he/she is working in administrative tasks, or in the final delivery of public goods/services. Additionally, we can identify which sector of public administration a public employee was assigned to work for: education, health, public works, sanitation, security, transportation and others. These occupational categories also allow us to classify workers according to the hierarchy level of their occupations in public administrations and firms (for instance, directors/managers vs. other employees). RAIS employment contract detail data contain for every worker information on reasons for hiring/firing, dates of employment, type of work contract (regular, temporary, short-term, apprenticeship), and, most importantly, information on how a worker was hired by the public sector-as a permanent civil servant, an appointee or a temporary worker. Based on the RAIS employer-employee data, Panel A in Table 1 presents descriptive statistics by city-year from 1995 to 2013 for the 5,412 municipalities used in our sample.

\subsection{Party Affiliation}

The party affiliation data contain individual-level information on all party members in Brazil. It was obtained from the Superior Electoral Tribunal (TSE) which actively tracks party affiliation of all registered voters in the country through an electronic platform named FiliaWeb. ${ }^{21}$ TSE keeps records of all past and current members of every party, and updates FiliaWeb twice a year (in April and October) based on the information about new and removed party members provided by every party. For each party, the affiliation data contain the full name of all party members, voter registration number, the municipality where each member registered, the date when every member affiliated with a party, and the date when an individual voter cancels its party affiliation (if applicable). Based on this information, we can identify every party member at any point in time. Based on the party affiliation data, Panel B in Table 1 shows descriptive statistics by city-year for the number of parties and party members in our final sample.

We merged RAIS with the party affiliation data based on each person's name, year of employment and affiliation, and location (metropolitan area). The match quality highly benefits from the fact that Brazilians usually have several surnames, since a common family tradition is for children to keep all surnames of both father and mother. The matching procedure allowed us to

\footnotetext{
${ }^{21}$ FiliaWeb was launched in 2009 and, in 2010, it became an official electronic platform through which parties submit information about their members to the Superior Electoral Tribunal (TSE). Before 2009, parties used to submit digital files to TSE containing information about their affiliates. In 2010, TSE integrated the previous party digital files to the information about affiliates submitted by parties through FiliaWeb to construct a unified dataset containing historical data of all party members in the country. This is the dataset used in this paper.
} 
identify the party affiliation (if any) of every public employee from all Brazilian municipalities. ${ }^{22}$ The largest share of matches, $80 \%$, are 1 to 1 matches. $^{23}$

\subsection{Public Finances}

The "Finanças do Brasil - Dados Contábeis dos Municípios" (FINBRA) dataset is our primary source of information on Brazilian municipal finances. It is organized by the Brazilian National Treasury Secretariat (STN) and it is produced by each municipal government annually. FINBRA includes information such as revenues from municipal taxes (property and services taxes), transfers revenue from state (ICMS) and central (FPM, PAB, FUNDEF/FUNDEB) governments, and expenditures to personnel or investment. It also presents expenditures disaggregated by functions like administration, janitorial services, public education and public health. Panel $\mathrm{C}$ in Table 1 presents basic descriptives by city-year for government expenditure, share of government expenditure devoted to personnel, and population size of the cities in our final sample.

\subsection{Elections}

Electoral data were obtained from the Superior Electoral Tribunal (TSE), which oversees national and local elections in Brazil. TSE records information on characteristics of candidates, political affiliation, and electoral results for all political offices in Brazil. Our dataset contain information on all municipality elections for mayors in 1996, 2000, 2004, 2008, and 2012, comprising data on pre-election characteristics of all candidates (gender, education background, marital status, wealth, and occupation), their respective parties and electoral coalitions, and the number of votes that each candidate received. We dropped from our data politicians that had their candidacy withdrawn or canceled. Table 2 presents basic descriptives by city-year for electoral years used in our final sample.

\subsection{Local Education and Health Outcomes}

Data on local education outcomes were obtained from the Brazilian Census for the years of 1991, 2000 and 2010. It contains information on educational achievement rates in all Brazilian

\footnotetext{
${ }^{22} \mathrm{We}$ conduct the match in five steps. In Step 1 observations are matched by exact full name. Step 2 matches use a "soundex" code of the surnames. Step 3 converts all middle names (not first and not last names) to middle initials. Step 4 all prepositions are eliminated (e.g. Da, De, Dos), and finally in Step 5 all prepositions are eliminated and middle names are converted to initials.

${ }^{23}$ The rest are split into 1:m, m:1, and m:m matches - see online appendix for details. Robustness tests show that our main estimates are unaffected by using a subsample that only includes 1:1 matches. Those results are available upon request.
} 
municipalities over those years. We examine the following education indicators: adult literacy, percentage of local population ages 15 and above who have more than 4 and 8 years of schooling, and percentage of local population ages 25 and above who have more the 11 years of schooling. ${ }^{24}$ These indicators measure local educational attainment and are used as long term outcomes to measure the effectiveness of the local education system (Harbison and Hanushek, 1992, Glewwe, 1999, Glewwe and Kremer, 2006)

We measure health conditions of the local population based on mortality rates. Using microdata from the Brazilian National System of Mortality Records (Datasus), we construct a dataset on mortality rate of individuals at different ages in all Brazilian municipalities for the year 1996 and 2013. In addition to the mortality rates of individuals below age 4 and between ages 14 and 74 , we also examine fetal ${ }^{25}$ and infant (before 1 year) mortality rates which are common proxies for the quality basic public health care delivery by local governments (Caldwell, 1986, and Riley, 2005).

\subsection{Final Data}

Our final data combine information from all the five separate aforementioned sources: RAIS employer-employee, party affiliation, public finance, election, education and health outcomes data. Because our estimated model, described in equation (5), specifies the outcome variables by party, city and calendar-year, we structured our data set at party-city-year to estimate the parameters of interest (i.e., $\theta_{\tau}$ and $\varphi_{\tau}$ ). Table 3 presents summary statistics of the final sample that we use to implement our empirical strategy.

\section{Results}

\subsection{Validity of the RD design}

Two conceptual concerns may invalidate our RD application. The first is the possibility that coalition characteristics change at the threshold, including pre-treatment outcome variables. Figure 3 tests for discontinuous changes around the margin of victory threshold, by plotting averages for the following variables in the year of the election: number of parties in the coalition, number of public employees affiliated with the leading parties, and the share of public employees

\footnotetext{
${ }^{24}$ Adult literacy rate is the percentage of people ages 15 and above who can both read and write with understanding a short simple statement about their everyday life.

${ }^{25}$ Fetal mortality corresponds to the number of fetal deaths occurring from the $22^{\text {nd }}$ complete week of gestation or 154 days, with fetuses weighing at least $500 \mathrm{~g}$ or height from $25 \mathrm{~cm}$, per thousand total births in the resident population in a given geographical area and year.
} 
affiliated with leading and supporting parties. Even though coalitions that win (lose) with large margins are indeed politically more (less) powerful, coalitions that win or lose by small margins are very similar to each other, on average.

The second concern is related to political coalitions having different pre-trends. Figure 4 presents estimates for a version of equation 5 that includes a number of relative years prior to the election. The year of the election is omitted. These pre-trend estimates show non-economically relevant differences in outcomes for winners and losers in the years leading up to an election.

\subsection{Winning coalition dynamic treatment effects}

Figure 5 plots the estimated dynamic patronage effects on the total number of employees affiliated with a party, along with $95 \%$ confidence intervals. ${ }^{26}$ The effects are split into $\theta_{\tau}$ for the party leading the winning coalition, and $\varphi_{\tau}$ for the other parties supporting it, as defined in equation (5). In the first year of the term, the winning party adds 11 additional affiliated public employees relative to the losing coalition. That estimate reaches a peak of 16 by the end of the first term, drops to 13 in relative year 5, and then stays relatively flat during the remaining years. Estimates for all winning supporting parties peak at 7 extra affiliated employees in years three and four, and never get below 6 even twelve years after an election. This stability or long term effect happens because it is difficult for future governments to fire civil servant employees with tenure.

The next outcome we analyze is the share of affiliated public employees. This metric has several advantages over the number of affiliated workers such as minimizing the importance of the largest cities and adjusting the estimates for the changing number of total public workers (affiliated or not) in the city over the years. Figure 6 shows that the leading party's share of employees increases almost 0.7 percentage points in the first year of the mayoral term - a very large proportional increase given that both 1 st and 2nd place candidates had a $5.7 \%$ share of public workers in the year of the election (see Figure 3 ). The gain increases to about 2 percentage points in relative years 3 and 4. At year 5, we observe the consequence of modelling the impact of other election cycles, as the relative benefits of winning an election drop to 1.2 percentage points - other parties are likely to win the next election and consequently reduce the share of employees from the wining party from the initial election.

Note that subsequent magnitudes from the patronage effect wane after that, but never go to zero, with the winning party still enjoying a 0.5 percentage point gain even twelve years after the

\footnotetext{
${ }^{26}$ These estimates are also reported in Columns (5) and (6) of Table 4. Columns (1) and (2) show an unconditional model, while columns (3) and (4) control for third degree polynomial of vote shares and its interactions.
} 
election. Given Brazil's legal context, it is no surprise that a small fraction of the total effect of winning an election on the share of wages earned by affiliates of the party is due to differential attrition. As explained above, public workers - especially civil servants - have a number of labor law protections that prevent them from being fired.

In Figure 6 we also show the shares of employees for the other parties in the leading coalition. The supporting parties increase their shares in the public sector by just under a percentage point during the first term and then drop to half-percent in the long term. ${ }^{27}$

Figure 7 shows that the importance of winning elections is even larger when considering the share of total wages devoted to party affiliates; not just the share of employees. ${ }^{28}$ While the dynamic patterns are relatively similar, the magnitudes of the effects for wages are twice as large in the first year of a mayoral term, and about $40 \%$ larger by relative year 4 . After that period, both effects - for share of wages and employees — become almost identical, indicating that the winning party loses certain leadership positions that pay more but becomes entrenched in many other sectors and occupations of the public administration. Overall, about 2/3 of the patronage effect during the first term is due to the leading party of the coalition, while $1 / 3$ is due to the supporting parties. In the long run the split becomes 60/40.

Further, we also split the wage share point estimates into bureaucratic and service-oriented occupations. Figure 8 shows that bureaucratic wage share corresponds to about $2 / 3$ of the total treatment effect on wage shares in relative year 1. Over time though, the share of the total effect due to bureaucrats declines as the winning party starts to fill up a disproportional number of serviceoriented positions, such as teachers and doctors. That trend becomes more obvious in year 5, when the effect on the share of bureaucrats becomes quite small. The remaining differential wage share enjoyed by the winning party becomes entirely attributable to service-oriented by the year 12 . The disproportional hiring of party members to service-oriented occupations is a practice that could lower the quality of services offered to the local population (Akhtari, Moreira, and Trucco, 2020). Later, in Section 7, we further examine the impact of patronage on the share and the composition of teachers and doctors, and their ultimate consequences on education and public health.

The point estimates above hide some of the dynamics of occupation of the local public sector in Brazil by the winning coalitions. To understand the process through which winning parties occupy local governments, we decompose these dynamic effects in four dimensions: (i) new hires without an affiliation prior to the election (new employees affiliated after elections), (ii) old hires

\footnotetext{
${ }^{27}$ The estimated coefficients plotted in Figure 6 are also reported in Columns (5) and (6) of Table 5.

${ }^{28}$ These estimates are also reported in Columns (5) and (6) of Table 6.
} 
without an affiliation prior to the election (old employees affiliated after elections), (iii) new hires affiliated prior to the election (hiring old party members), and (iv) old hires affiliated prior to the election (old employees from the opposing party). ${ }^{29}$ Panels $\mathrm{A}$ and $\mathrm{B}$ in Table 7 present the decomposition of the estimated effects in those four dimensions for the first four years after an election. The first year of the party occupation process starts with hiring old party members of wining coalitions (accounting for 51 percent) and lowering both employment and wage shares of old employees affiliated with losing coalitions (43 percent). Later on, party members affiliated after the election are recruited by local governments, and old public employees join the parties of the wining coalition. These new and old employees affiliated after elections account for only a small percentage of the first-year effect, while in the third year they account for 39 percent of the patronage.

\section{Mechanisms}

\subsection{Intergovernmental Transfers}

A potential explanation for the high levels of patronage observed in Brazilian local governments relates to the local tax system, which is largely based on federal and state transfers. ${ }^{30}$ However, empirically evaluating the casual effect of transfers on municipal employment of party members is not an easy task. An unbiased estimator of that effect would require a comparison of the employment of party members in two sets of municipalities with similar characteristics, where one set randomly receives more intergovernmental transfers than others. We use a research design that mimics this ideal design by exploiting discontinuous changes in federal transfers (FPM) to municipalities at given population thresholds. While municipalities belonging to a particular population bracket receive the same amount of federal and state transfers in a given year, municipalities slightly above (below) the upper (lower) bound of each bracket receive, on average, 20 percent more (less) revenues. Therefore, small variations in city population around predetermined thresholds provide exogenous variation in transfers received by municipalities which allows us to identify casual effects of transfers on the amount of patronage. ${ }^{31}$

To that end, we augment the econometric model described in equation (5) to account for the discontinuous changes in federal transfers (FPM) to municipalities at given population thresholds.

\footnotetext{
${ }^{29}$ A tiny fraction of the total effect is due to affiliates switching parties after the election, so we do not consider them here.

${ }^{30}$ Federal transfers are the main source of funding for municipalities (85 percent), while local taxes (property and service taxes, building permits fees) represent only 6 percent of the budget, on average.

${ }^{31}$ Other examples of research using FPM transfers include Brollo, Nannicini, Perotti and Tabellini (2013), Litschig and Morrison (2013), Gadenne (2017), and Corbi, Papaioannou and Surico (2019).
} 
In practice we estimate interaction effects with the winning coalitions, comparing patronage effects on both sides of a population threshold. ${ }^{32}$ The results reported in Figure 9 reveal that more FPM transfers (for cities on the right side of each population threshold) generally increase the share of wages of winning coalition affiliates. Note the effect is only significant for the cities around the first threshold with population close to 10,000 , where the importance of transfers is much higher on a per capita basis.

Those findings are not only interesting per se, but also because they show how the design of local public finance based on transfers can deliver negative consequences to public expenditures related to personnel decisions. Local expenditures financed by local revenues may be a more appropriate way to bind politician's opportunistic behavior.

\subsection{Accountability Channels}

Many researchers report large discrepancies in the quality of governments across countries, with corruption and rent-seeking type behavior being more prevalent in the public sectors of less developed regions. ${ }^{33}$ In this sub-section, we test if similar patterns can be detected across cities in Brazil, by directly estimating heterogeneity in the magnitude of the occupation of the public sector by winning parties according to different measures of accountability and quality of governance.

City Size. Our first test splits our final sample in four quartiles by city size, with city size based on year 2000 population. Smaller towns in Brazil are generally poorer, have less private sector options, and parties are close-knit clubs where party membership usually coincides with family and friendship ties. Figure 10.A shows the dynamic treatment effect of winning an election on party wage share varying by quartile of city size. Estimates for the $1^{\text {st }}$ quartile are about 6 times larger than the magnitude of estimates for the large cities in the $4^{\text {th }}$ quartile, in the third year of a mayoral term.

Media Presence. Recent studies on media have shown that the presence of newspapers and radio amplifies citizens' knowledge of public policies and of politics, which affect voters' perception of politicians and turnout. ${ }^{34}$ In Brazil, Ferraz and Finan (2008) find that the release of

\footnotetext{
${ }^{32}$ A detailed description of the methodology used in those estimations are in the Online Appendix. It also presents tests that guarantee the validity of regression discontinuity design.

${ }^{33}$ See, for instance, Shleifer and Vishny (1993), Mauro (1995) and La Porta et al. (1999).

${ }^{34}$ Besley and Burgess (2002), for instance, show that governments in India are more responsive in their relief of shocks to places with higher newspaper circulation and where voters are more informed. Stromberg (2004) finds that U.S. counties with more radio listeners received more relief funds from the New Deal program. Gentzkow (2006) discusses
} 
the audit outcomes has a significant impact on incumbents' electoral performance, and that these effects are more pronounced in municipalities where local radio is present to divulge the information. Thus, empirical evidence suggests presence of media in a municipality is good proxy for accountability and quality of governance at the local level.

To obtain information on the presence of media in a municipality, we rely on a survey from the Brazilian Institute of Geography and Statistics (IBGE), named as Perfil dos Municípios Brasileiros, which contains information of key measures of the availability of media in every Brazilian city. This city-level survey provides information on the presence of local press (newspapers, magazines), local radio, existence of TV coverage and availability of internet connection in a municipality.

We then estimate equation (5) with the interaction of winning coalitions with the presence of local radio, local press, TV coverage, and availability of internet in a municipality. Results are presented in Figure 10.B. The presence of local media significantly reduces the allocation of wages to party members of the winning coalition. We find the wage share of individuals affiliated to the elected party (in the third year after an election) is about 1.5 percent points smaller in cities with local press, 2 percent points smaller in cities with radio, 2 percent points smaller in cities with TV coverage, and 1.4 percent points smaller in cities with availability of internet. These results suggest that the presence of local media limits patronage practices in local Brazilian governments.

Audits. Government audits of public resources in Brazil affect incumbents' electoral performance of corrupt politicians (Ferraz and Finan, 2008, 2011), and reduce corruption (Avis, Ferraz and Finan, 2018). Following Avis, Ferraz and Finan (2018), we investigate whether government audits of public resources can affect personnel hiring decisions in Brazilian local governments, considering that audits increase the perceived non-electoral costs of engaging in misuse of public funds.

The anti-corruption program targeted at municipal governments was launched in 2003 by CGU (Controladora Geral da União), Brazil's controller's office. The program, named Programa de Fiscalização por Sorteios Públicos (Monitoring Program with Public Lotteries), randomly audits municipalities' use of federal funds. Its initial audits were performed on 26 randomly selected municipalities across different states, and then the program grew towards auditing 60 municipalities

\footnotetext{
how the introduction of television in the United States resulted in a sharp drop in newspaper and radio consumption, which reduced citizens' knowledge of politics and consequently led to lower voter turnout. Gentzkow, Glaeser, and Goldin (2006) demonstrate that changes between 1870 and 1920 in the U.S. newspaper industry are related to the reduction of corruption in U.S. politics in the same period.
} 
per lottery. The lotteries are held publicly in conjunction with the national lottery in Brasília, and all municipalities with a population of up to 500,000 inhabitants are eligible for selection. As of February 2015, there have been 2,241 audits across 40 lotteries in 1,949 municipalities. Once a municipality is chosen, the CGU gathers information on all federal funds transferred to the municipal government during the previous three to four years and issues a random selection of inspection orders. Each one of these orders stipulates an audit task for a specific government project (e.g. school construction, purchase of medicine, etc.) within a specific sector. Once these inspection orders are determined, 10 to 15 auditors are sent to the municipality for one to two weeks to examine accounts and documents, inspect for the existence and quality of public work construction, and verify the delivery of public services. After the inspections are completed, a detailed report describing all identified irregularities is submitted to the central CGU office in Brasília. The central unit compiles all information and publishes a report on the internet. ${ }^{35}$

We create an indicator for whether a city had an audit in the previous mayoral term, and also interact the indicator with the winning coalition terms. As a placebo test, we also estimate similar models that specifies if a city had an audit in the current term, or if the audit will happen in the next term. The results presented in Figure 10.C show that having a future audit does not change the current behavior of all parties and of the winning coalitions. The same conclusion is reached for audits in the current term, as presumably the winning coalition did not have enough time to potentially react to the federal audits. However, the last set of estimates shows the existence of audit in city in the term before an election significantly reduces allocation of public jobs to party members of the elected coalition. The wage share of individuals affiliated with the elected party is about 1.1 percent smaller in municipalities that had an audit.

\subsection{Political Economy Channels}

Party ideology. Another potential explanation for the disproportional occupation of the public sector by winning coalitions is ideology. The political economy literature gives many examples of left-leaning parties with strong preferences for bigger and more redistributive governments. These parties may decide to even control lower levels of the bureaucracy with party members, in order to allegedly better carry out their mission. We test this assumption by first estimating a version of equation (5) that interacts the winning party terms with dummies for each

\footnotetext{
${ }^{35}$ These reports are also sent to the Federal Courts of Accounts (TCU), the Federal Prosecutors' Office (MPF), the local judiciary, the Federal Police, and to the municipal legislative branch. For more details about the CGU's government audits, see Ferraz and Finan (2008, 2011), Brollo, Nannicini, Perotti and Tabellini (2013), and Avis, Ferraz and Finan (2018).
} 
of the 33 parties in Brazil. This model produces party-specific estimates of the wage share, all of them shown in Figure 11.A. It is noteworthy that three of the largest parties with respect to patronage as leading parties, PP (right leaning), PMDB (center leaning) and PT (left leaning), were also the parties engulfed in the corruption scandal of Petrobras, that ultimately led to the impeachment of former president Dilma Rousseff in 2015.

Next, we assign the ideology index from Power and Zucco $(2009,2012,2019)$ to fifteen of those parties. This index varies from -2.5 to 2.5 , with parties closer to -2.5 being more left leaning, while a score close to 2.5 means right leaning. A score around 0 indicates a centrist party. We then interact the treatment dummies in equation (5) with party ideology - left, center, and right, following the 2017 ideology index constructed by Power and Zucco (2019). The results presented in Figure 11.B reveal little difference on dynamic treatment effects of winning an election by party ideology.

Rent-seeking pressure. The allocation of public jobs to party members indicates a quid pro quo relationship between the party in power and its political supporters, in which public jobs are used as a reward to supporters for their votes and/or campaign efforts (Calvo and Murillo, 2004; Stokes 2009, Folke, Hirano and Snyder, 2011). Accordingly, the higher the number of political supporters of party, the higher should be the effect of a party election on the wage share of public employees affiliated to the winning party.

In order to more carefully investigate whether party size determines the dynamics of government occupation, we further interact treatment dummies in equation (5) with a pre-election measure of party size that varies by city (i.e., the share of party affiliates in each city in the year before an election). Figure 11.C shows the interaction effect for quartiles of party size. Our results reveal that the dynamic patronage effects do increase with the pre-election size of competing parties, consistent with rent-seeking pressure exerted by political supporters.

\section{Consequences for Public Expenditures and Service Delivery}

Having measured the short and long run effects of government personnel decisions based on the political affiliation of individuals, we can now estimate the impact of such political occupation of the public sector on public finances and on public service provision. As reported above, cities have little discretion with respect to total revenues, so any potential consequence would be observed on the composition of public expenditures. We use two methods to estimate the 
effect of patronage on expenditures with affiliated employees: i) model predictions, and ii) heterogeneity in patronage by city.

Model predictions. To estimate the distortion caused by patronage on the composition of public employees, we first estimate the share of city employees with party affiliation in absence of patronage effects, and then we compare that with the estimated share of city employees with party affiliation predicted by our complete model, which contains political patronage (this prediction is very similar to the descriptives in Figure 1). The difference between these figures will reveal the consequences of government personnel decisions based on party affiliation.

To obtain our estimate of the share of city employees with party affiliation in the presence of patronage, we proceed as follows. First, we predict the estimated equation (5) for the share of public employees associated to each party. This procedure generates the share of city employees affiliated to every Brazilian in every city in all years of our sample. Next, we sum those shares across all parties for every year from 1995 to 2013 to obtain the share of city employees affiliated with a party for every city and year of our sample. To estimate the share of city employees with party affiliation in absence of patronage effects, we repeat the same procedure described above, but turn off the coefficients associated to the variables $b_{j c, t-\tau}^{l}$ and $b_{j c, t-\tau}^{s}$ (which indicate the leading and supporting parties of a winning candidate, respectively). This generates the time evolution of the predicted share of city employees in every city in our sample without a patronage effect.

Figure 12 plots the predicted share of city employees with party affiliation with and without patronage. The continuous line in Figure 12 reveals that the predicted share of city employees with party affiliation in the presence of patronage spans from 20.73 percent in 1996, the year of first election in our sample, to 30.8 percent in 2013 , the last year in our sample. The dashed line in Figure 12 shows the estimated share of city employees with party affiliation in the absence of patronage effects. Note that our model predicts an increase of the share of city employees with party affiliation during our period of analysis, disregarding any patronage effect. The share of city employees with party affiliation without patronage range from 20.73 percent in 1996 to 24.9 percent in 2013. Finally, the dashed-dotted line plots the difference between the share of city employees with party affiliation (predicted in our complete model) and the estimated share of city employees with party affiliation in the absence of patronage. This figure reveals that over the course of nearly two decades, patronage is responsible for an increase of 5.85 percent of share of city employees with party affiliation, corresponding to 56 percent of the increase of the share of city employees with party affiliation since 1996. 
Patronage by city. What are the long term consequences of the political occupation of civil service positions on public finances and the quality of local public goods? To answer this question we first use our dynamic RD model to estimate a long term patronage index for each city in Brazil. We rely on our model from equation (5) to estimate a specific patronage effect for each city in the country, by interacting a complete set of city indicators with the terms $b_{p c, t-3}^{l}$ and $b_{p c, t-3}^{s}$. Our final patronage index by city adds the effects for both leading and supporting parties, and it represents the average patronage, in the third year of a mayoral term, over the course of all elections in our sample. ${ }^{36}$ Figure 13 shows a map of Brazilian cities, color coded by quintiles of the distribution of this patronage index by city. From this image, it is clear that high levels of patronage by city are not solely concentrated in select regions, but rather are dispersed across the country.

Second, we model differences in long term outcomes for each city as a function of long term changes in political occupation, i.e., changes in the public sector wage share devoted to affiliated personnel. ${ }^{37}$ Our previous analysis showed that not all wage expenses with affiliated employees are due to patronage, so we instrument it with the city level patronage index - which solely relies on the exogenous variation from the RD model. The first-stage regression of change in occupation has an estimated coefficient for the city patronage index of $0.416(0.041) .{ }^{38}$ This estimate reveals that an increase of one standard deviation (i.e., 8.93 percentage points) in the patronage index leads to a raise of 3.71 percentage points in wage expenses with affiliated employees. ${ }^{39}$ Figure 14 shows a scatter plot of this strong first-stage relationship. Estimates from the two-stage least square models are shown in Tables 9, 10, and 11, and refer to these estimates as patronage effects.

In Table 9 we report public finance outcomes. Columns (1) and (2) show estimates for the share of personnel expenses and investments, relative to the total city budget. Both estimates are small and not statistically different from zero, suggesting that political occupation does not affect share of expenditures devoted to personnel and capital investments. Nevertheless, Column (3) shows a positive effect of political occupation on the share of total expenditures allocated towards affiliated civil servants. Every one percentage point increase in political occupation (instrumented

\footnotetext{
${ }^{36}$ Note that this city specific patronage index could be noisy because of the relatively small number of parties and elections per city. But, following Chetty and Hendren (2018), we tested a combination of the city-specific effects with raw data on shares of party affiliation employees dived by the share of citizens with party affiliation, and we found very similar results. Our final patronage index, therefore, only uses estimates from our final model.

${ }^{37}$ In practice we calculate total wages paid to affiliated public employees in a year, and divide it by the total wage bill in a city in that same year. Next we calculate differences in that variable between 2002 and 1995.

${ }^{38}$ This first stage model also includes state-fixed effects and changes in total city population and total expenditures. The estimated regression is in Table A2 in the Online Appendix.

${ }^{39}$ The mean (standard deviation) of the patronage index and of the wage expenses with affiliated employees are, respectively, 5.3 (8.93) and 14.87 (12.34) percentage points. See Table A2 in the Online Appendix.
} 
by the patronage index) increases city resources devoted to affiliated civil servants by 0.329 percentage points. Column (4) shows a symmetrically opposite estimate for the share of resources devoted to public employees not affiliated to political parties $(-0.293)$, indicating a practically oneto-one crowed out effect. ${ }^{40}$

In Table 10 we estimate the impact of political occupation on the wage share and the composition of teachers and doctors employed by public governments in Brazilian cities. These two classes of public workers are keys for provision of high quality public education and basic health care in Brazilian municipalities. On average, Brazilian cities have increased their share of budget expenses with teachers and doctors by 4.3 and 0.67 percentage points, respectively, between 1995 and 2012. ${ }^{41}$ But patronage reverse some of these gains. Column (1) and Column (2) show that the increase in political occupation of civil service positions due to patronage reduces teachers and doctors expenses relative to the total city budget, indicating that those two important classes of local public employees for public service provision have been crowded out for other expenditures. Each percentage point increase in affiliated civil servants reduces city expenses with teachers and doctors by 0.094 and 0.043 percentage points, respectively. Further, in Column (3) and (4), we find that expenses with affiliated teachers in fact increase slightly, while the major reduction in expenses with teachers occurs only for non-affiliated teachers. A similar compositional effect is observed for doctors in Columns (5) and (6): only the fraction of non-affiliated doctors reduces, and the fraction of expenses with affiliated doctors remain unchanged by the effect of political occupation.

This change in the quantity and quality of teachers can deteriorate local education outcomes (Glewwe and Kremer, 2006). For context, on average Brazilian cities have increased the educational achievement of its citizens from early 1990s to 2010 - the share of local population with more than 8 years of education increased 25 percentage points while the share of local population with more than 11 years of education increased 20 percentage points. ${ }^{42}$ But those increasing levels of education were attenuated in cities with higher levels of patronage. In Table 11.A we show the estimated effect of political occupation, instrumented by patronage index, on long term educational achievement. Columns (1) and (2) show that a one percentage point increase in political occupation reduces the share of individuals with more than 11 years of education by

\footnotetext{
${ }^{40}$ Note that the explanatory variable in Table 9 is computed out of the total wages of a city, while the outcome variables in Columns (4) and (5) of Table 9 are based on the wages (affiliated and non-affiliated, resp.) divided by city's total expenditures.

${ }^{41}$ Table A3 and A4 in the Online Appendix present descriptive statistics for local public outcomes and for share of total expenditures allocated towards teachers and doctors.

${ }^{42}$ The descriptive statistics of local education outcomes at the municipality level for the years of 1991 and 2010 , and for their change over that period are in Table A5 in the Online Appendix.
} 
0.376 percentage points, and also reduces the share of individuals with more than 8 years of education by 0.116 percentage points. Note that one-standard deviation increase in the patronage index occupation (which is 8.93) leads to a reduction in 1.4 percentage points in the share of local citizens with 11 or more years of education. This is a non-negligible effect given the increase of 20 percentage points in the share of individuals with more than 11 years of education driven by federal government policies to improve education attainment in Brazil (Ferreira, Bourguignon and Leite, 2003; Glewwe and Kassouf, 2012; Silveira at al., 2017). Such long term outcomes corroborate the short-term negative consequences of displacing school principals after municipal elections found in Akhtari, Moreira and Trucco (2020). The remaining columns reveal that estimates for adult literacy rate, and for the percentage of local population ages 15 and above who have less and more than 4 years of schooling, are not statistically different from zero.

Similarly, suppressing the quantity and quality of doctors can damage local health conditions (Das et al., 2008, Das and Hammer, 2014), especially in Brazil where doctors are local leaders of health professional teams in primary care programs (Rocha and Soares, 2010) ${ }^{43}$ For context, mortality rates in Brazilian cities have had mixed results from 1990s to 2013: Total yearly mortality rate per 100,000 individuals increased from 513 to 624, but this was concentrated in the population of ages 4 to 74 . Mortality rates for children younger than 4 declined, on average, from 46 to 20 per $100,000 .^{44}$

Political occupation seems to negatively impact both outcomes. In Table 11.B we examine their effect on health conditions of the local population proxied by mortality rates of individuals at different ages. Column (1) and (2) in Table 11.B show that more political occupation increases fetal and infant (before 1 year) mortality rates. Colum (3) and (4) in the same table show that an increase in mortality throughout the age distribution (i.e., mortality of individuals below ages 4 and between 4 and 74), with children young than 4 having a higher mortality rate of 1 per 100,000 for every percentage point increase in wage expenses with affiliated employees.

To get a sense of the magnitude of political occupation long-term effect on mortality, we focus on the effect on mortality of individuals under age 4. Among our mortality indicators, this mortality rate tends to reflect better the health conditions of individuals in a city than the other ones as it captures the mortality of a wide range of individuals that are probably born and benefit from the public health care services in a city, and unlikely to be affect from the mortality of migrants.

\footnotetext{
${ }^{43}$ The demographic and development literature, for instance, have identified that such kind of public health care programs are key factors promoting improvements in health and reduce mortality rates for acting in prevention and early detection of diseases (Caldwell, 1986; Riley, 2005 and 2007; Soares, 2007).

44 Table A6 in the Online Appendix presents descriptive statistics mortality rate of individuals at different ages in Brazilian municipalities for the year of 1996 and 2013, and for their change over that period.
} 
Our estimates reveals that an increase of one standard deviation (i.e., 8.93 percentage points) in the patronage index over 1996-2013 leads to a raise in mortality of 3.84 children under age 4 per 100,000 in the period. This effect corresponds to 15 percent of the impact on mortality of eight years of the Family Health Program in Brazil - a major and successful public health care program that leaded to important reduction in mortality throughout the age distribution (Rocha and Soares, 2010). That indicates that the magnitude of patronage long-term effect on mortality is considerable. $^{45}$

The results in Table 11.A and 11.B indicates that patronage leads to a non-negligible longlast negative impact on the quality of the two most important public services delivered by Brazilian municipalities: education and health care.

\section{Conclusion}

Our analysis shows that public sector personnel decisions can be heavily influenced by democratic election outcomes. Using a comprehensive data set of local elections, public employees, party affiliations, and public finances from almost all Brazilian cities, we find that winning parties (leading and supporting) increase their shares of public employees by 3 percentage points after an election. They seize an even larger share of wages, 4 additional percentage points compared to pre-election means. These patronage effects can last longer than a decade, with winning coalitions also occupying civil servant jobs that to perform key service-oriented tasks in education and public health. The increase in political occupation of governmental jobs is not correlated with political ideology though. Instead, it is correlated with the level of city development and party size. Moreover, lack of accountability is a key factor in the process of governmental occupation.

The impact of the political occupation in the composition of public expenditures is quite large, as hiring politically connected workers crowds out non-affiliated teachers and doctors. Such change in the composition of public workers has negative long-term negative effect on the public service delivery, as education and health. Overall, the political occupation of civil servant positions in Brazilian cities resulted in higher mortality rates and low years of schooling, and accounted for more than half of the dramatic increase in public sector political employment since the Brazilian re-democratization.

\footnotetext{
${ }^{45}$ Rocha and Soares (2010) show that municipalities eight years into the Family Health Program in Brazil experienced a reduction of 26 per 100,000 in mortality of children between 1 and 4, as compared to municipalities not covered by the program.
} 


\section{References}

Acemoglu, D., Naidy, S., Restrepo, P., and Robinson, J., 2015. "Democracy, Redistribution, and Inequality. " In Handbook of Income Distribution, v. 2, 1885-1996, edited by Atkinson, A. and Bourguignon, $\mathrm{F}$.

Aidt, T. and Jensen, P., 2013. "Democratization and the Size of Government: Evidence from the Long $19^{\text {th }}$ Century. " Public Choice, 157(3-4), 511-542.

Akhtari, M., Moreira, D., and Trucco, L., 2020. "Political Turnover, Bureaucratic Turnover, and the Quality of Public Services." The American Economic Review, Forthcoming.

Alesina, A., 1988. "Credibility and Policy Convergence in a Two-Party System with Rational Voters." The American Economic Review, 78 (4), 796-805.

Anagol, S. and Fujiwara, T., 2016. "The Runner-Up Effect." Journal of Political Economy, 124(4), 927-991.

Avis, E., Ferraz, C., Finan, F., 2018. " Do Government Audits Reduce Corruption? Estimating the Impacts of Exposing Corrupt Politicians." Journal of Political Economy, 126 (5), 1912-1964.

Besley, T., and Burgess, R. 2002. "The Political Economy of Government Responsiveness: Theory and Evidence from India." The Quarterly Journal of Economics, 117(4), 1415-1452.

Besley, T., and Case, A., 2003. "Political Institutions and Policy Choices: Evidence from the United States." Journal of Economic Literature, 41(1), 7-73.

Besley, T., and Coate, S., 1997. "An Economic Model of Representative Democracy." The Quarterly Journal of Economics, 112 (1), 85-114.

Boyne, George, Oliver James, Peter John, and Nicolai Petrovsky. 2010. "Does Political Change Affect Senior Management Turnover? An Empirical Analysis of Top-tier Local Authorities in England." Public Administration, 88(1), 136-153.

Brollo, F., Nannicini, T., Perotti, R., Tabellini, G., 2013. "The Political Resource Curse." American Economic Review, 103 (5), pp. 1759-96.

Brollo, F., Forquesato, P., and Gozzi, J.C., 2017. "To the Victor Belongs the Spoils? Party Membership and Public Sector Employment in Brazil." Working Paper.

Cameron, C., de Figueiredo, J. M., and Lewis, D., 2016. "Public Sector Personnel Economics: Wages, Promotions, and the Competence-Control Trade-off." NBER working paper 22966.

Caldwell, J., 1986. Routes to Low Mortality in Poor Countries. Population and Development Review, 12(2), 171-220.

Calvo, E., and Murillo, M.C,. 2004. "Who delivers? Partisan clients in the Argentine electoral market. " American Journal of Political Science, 48(4):742-757.

Cellini, S., Ferreira, F, and Rothstein, J., 2010 "The Value of School Facility Investments: Evidence from a Dynamic Regression Discontinuity Design." The Quarterly Journal of Economics, 125(1), 215-261. 
CGU, Controladoria Geral da União, 2015. "Relatório de Auditoria n. 201505051." CGURegional/PR. Secretaria Federal de Controle Interno. Presidência da República do Brasil. https://auditoria.cgu.gov.br/download/12236.pdf. (accessed February 16, 2021).

Chetty, R. and Hendren, N. 2018. "The Impacts of Neighborhoods on Intergenerational Mobility II: County-Level Estimates." The Quarterly Journal of Economics, 133 (3), 1163-1228.

Chu, J., Fisman, R., Tan, S., Wang, Y., 2020. Hometown Ties and the Quality of Government Monitoring: Evidence from Rotation of Chinese Auditors, NBER Working Paper No. 27032.

Coppedge, M., 1997. "A Classification of Latin American Political Parties." Helen Kellogg Institute for International Studies, Working paper \#244.

Colonnelli, E., Prem, M., and Teso, E., 2020. "Patronage and Selection in Public Sector Organizations." The American Economic Review, 110 (10), 3071-99.

Corbi, R., Papaioannou, E., and Surico, P., 2019. "Regional Transfer Multipliers". Review of Economic Studies, 86 (5), 1901-1934.

Dal Bó, E., Finan, F., Folke, O., Persson, T., and Rickne, J., 2017. "Who Becomes a Politician?" The Quarterly Journal of Economics, 132 (4), 1877-914.

Dal Bó, E., Finan, F., and Rossi, M., 2013. "Strengthening State Capabilities: The Role of Financial Incentives in the Call to Public Service." The Quarterly Journal of Economics, 128 (3), 1169-218.

Das, J., Hammer, J. and Leonard, K. 2008. "The Quality of Medical Advice in Low-Income Countries." Journal of Economic Perspectives, 22 (2): 93-114.

Das, J. and Hammer, J. 2014. "Quality of Primary Care in Low-Income Countries: Facts and Economics." Annual Review of Economics, 6 (1), 525-553.

Deserranno, E., 2019. "Financial incentives as signals: experimental evidence from the recruitment of village promoters in Uganda." American Economic Journal: Applied Economics, 11(1), 277317.Dix-Carneiro, R., 2014. "Trade Liberalization and Labor Market Dynamics." Econometrica, $82,825-885$.

Dix-Carneiro, R., and Kovak, B., 2017. "Trade Liberalization and Regional Dynamics." American Economic Review, 107 (10), 2908-2946.

Downs, A., 1957. "An Economic Theory of Political Action in a Democracy." Journal of Political Economy, 65 (2), 135-150.

Dull, Matthew, Patrick S. Roberts, Michael S. Keeney, and Sang Ok Choi. 2012. "Appointee Confirmation and Tenure: The Succession of Federal Agency Appointees, 1989-2009." Public Administration Review, 72(6), 902-913.

Eggers, A., and Hainmueller. J., 2009. "MPs for Sale? Estimating Returns to Office in Post-war British Politics." American Political Science Review, 103(4). 513-33.

Fang, H., Li, Z., Xu, N., and Yan, H., 2018. "In the Shadows of the Government: Relationship Building During Political Turnovers." Working Paper.

Ferraz, C., and Finan, F., 2008. "Exposing Corrupt Politicians: The Effect of Brazil's Publicly Released Audits on Electoral Outcomes." Quarterly Journal of Economics, 123 ( 2), 703-745.

Ferraz, C., and Finan, F., 2011. "Electoral Accountability and Corruption: Evidence from the Audits of Local Governments." The American Economic Review, 101(4), 1274-1311. 
Ferreira, F., and Gyourko, J., 2009. "Do Political Parties Matter? Evidence from U.S. Cities." The Quarterly Journal of Economics, 124(1), 349-397.

Finan, F., Olken, B., and Pande, R., 2015. "The Personnel Economics of the State." In Duflo, E. and Banerjee, A., eds. Handbook of Field Experiments, Elsevier, North Holland.

Ferreira, F., Bourguignon, F and Leite, P., 2003. "Conditional Cash Transfers, Schooling, and Child Labor: Micro-Simulating Brazil's Bolsa Escola Program." The World Bank Economic Review, 17(2),229-254.

Fisman, R., and Gatti, R., 2002. "Decentralization and Corruption: Evidence from U.S. Federal Transfer Programs. " Journal of Public Economics, 83, 325-345.

Fisman, R., Schulz, F., Vig, V., 2014. "The Private Returns to Public Office." Journal of Political Economy, 122 (4), 806-862.

Folke, O., Hirano, S., and Snyder, J.M, 2011. "Patronage and Elections in U.S. States." American Political Science Review, 105, 567-585.

Fujiwara, T., 2015. "Voting Technology, Political Responsiveness, and Infant Health: Evidence from Brazil. " Econometrica, 83(2), 423-464.

Gadenne, L., 2017. "Tax Me, But Spend Wisely: Sources of Public Finance and Government Accountability." American Economic Journal: Applied Economics, 9, 274-314.

Gagliarducci, S. and Manacorda, M. 2020. "Politics in the Family: Nepotism and the Hiring Decisions of Italian Firms." American Economic Journal: Applied Economics, 12 (2): 67-95.

Gentzkow, M. A., E. L. Glaeser, and Goldin, C., 2006. "The Rise of the Fourth Estate: How Newspapers Became Informative and Why It Mattered," in Corruption and Reform: Lessons from Americas History, E. L. Glaeser and C. Goldin, eds. (Chicago: University of Chicago Press, 2006).

Gentzkow, M. A., 2006. "Television and Voter Turnout." The Quarterly Journal of Economics, 121(3) (2006), 931-972.

Glaeser, E., Ponzetto, G., and Shapiro, J. 2005. "Strategic Extremism: Why Republicans and Democrats Divide on Religious Values." The Quarterly Journal of Economics, 120 (4), 1283-1330.

Glewwe, P., 1999. "The Economics of School Quality Investments in Developing Countries." St. Martin's Press, New York.

Glewwe, P. and Kassouf, A., 2012. "The Impact of the Bolsa Escola/Familia Conditional Cash Transfer Program on Enrollment, Dropout Rates and Grade Promotion in Brazil." Journal of Development Economics, 97 (2), 505-517.

Glewwe, P. and Kremer, M. 2006., "Schools, Teachers, and Education Outcomes in Developing Countries." Handbook of the Economics of Education, 2, 945-1017.

Harbison, R., Hanushek, E., 1992. "Educational Performance of the Poor: Lessons from Rural Northeast Brazil." Oxford University Press.

Imbens, G. and Angrist, J., 1994. "Identification and Estimation of Local Average Treatment Effects." Econometrica, 62 (2), 467-475.

Jiang, J., and Zhang, M., 2020. "Friends with benefits: Patronage networks and distributive politics in China." Journal of Public Economics, 184, 104-143. 
La Porta, R., Lopez-de-Silanes, F., Shleifer, A., and Vishny, R., 1999. "The Quality of Government." Journal of Law, Economics and Organization, 15 (1), 222-279.

Lee, D. S., 2008. "Randomized Experiments from Non-random Selection in U.S. House Elections." Journal of Econometrics, 142 (2), 675-697

Lee, D., Moretti, E., and Butler, M., 2004. "Do Voters Affect or Elect Policies? Evidence from the U. S. House." The Quarterly Journal of Economics, 119 (3), 807-859.

Litschig, A., and Morrison, K., 2013. "The Impact of Intergovernmental Transfers on Education Outcomes and Poverty Reduction." American Economic Journal: Applied Economics, 5 (4), 206240.

Mauro, P., 1995. "Corruption and Growth." The Quarterly Journal of Economics, 110 (3), 681712 .

Menezes-Filho, N.A, Muendler, M.-A., and Ramey, G., 2008. "The Structure of Worker Compensation in Brazil, with a Comparison to France and the United States." The Review of Economics and Statistics, 90, 323-346.

MPSP, Ministério Público do Estado de São Paulo, 2019. "Processo $\mathrm{n}^{\mathrm{o}} 2235750$ 84.2019.8.26.0000." Governo do Estado de São Paulo. https://www.jusbrasil.com.br/processos/242514676/processo-n-2235750-8420198260000-do-tjsp. (accessed February 16, 2021).

Power, T. and Zucco Jr., C., 2009. "Estimating Ideology of Brazilian Legislative Parties, 19902005." Latin American Research Review, 44 (1), 218-246.

Power, T. and Zucco Jr., C., 2012. "Elite Preferences in a Consolidating Democracy: The Brazilian Legislative Surveys, 1990-2009." Latin American Politics and Society, 54(4), 1-27.

Power, T. and Zucco Jr., C., 2019. "Fragmentation Without Cleavages? Ideology, Policy Preferences, and Political Polarization in Brazil." Comparative Politics, Forthcoming .

Querubin, P., and Snyder, J., 2009. "Returns to U.S. Congressional Seats in the Mid-19th Century." In The Political Economy of Democracy, edited by Enriqueta Aragones, Carmen Bevia, Humberto Llavador, and Norman Schofield. Madrid: Fundacion BBVA.

Riley, J., 2005. Poverty and Life Expectancy. Cambridge University Press, Cambridge.

Riley, J., 2007. Low Income, Social Growth, and Good Health - A History of Twelve Countries. University of California Press, Berkeley and Los Angeles.

Rocha, R. and Soares, R., 2010. Evaluating the Impact of Community-Based Health Interventions: Evidence from Brazil's Family Health Program. Health Economics, 19(S1), 126-158.

Shleifer, A. and Vishny, R., 1993. "Corruption." The Quarterly Journal of Economics, 108 (3), 599-617.

Silveira, I., Lima, J., Teixera, E., Silva, R. 2017. "Avaliação do Efeito do Fundeb sobre o Desempenho dos Alunos do Ensino Médio no Brasil." Pesquisa e Planejamento Econômico, 47 (1), 7-44.

Soares, R., 2007. On the Determinants of Mortality Reductions in the Developing World. Population and Development Review, 33(2), 247 - 287. 
Stokes, S.C., 2009. "Political Clientelism. " In: The Oxford Handbook of Comparative Politics. Oxford: Oxford University Press.

Stromberg, D., 2004. "Radio’s Impact on Public Spending. " Quarterly Journal of Economics, 119 (1), 189-221.

Tiebout, C., 1956. "A Pure Theory of Local Expenditures." The Journal of Political Economy, 64 (5), 416-424.

Xu, G., 2018. " The Costs of Patronage: Evidence from the British Empire. " American Economic Review, 108(11), 3170-98.

Weaver, J. 2018. " Jobs for Sale: Bribery and Misallocation in Hiring. " Unpublished 


\section{Figure 1: Share of City Employees Affiliated with a Party}

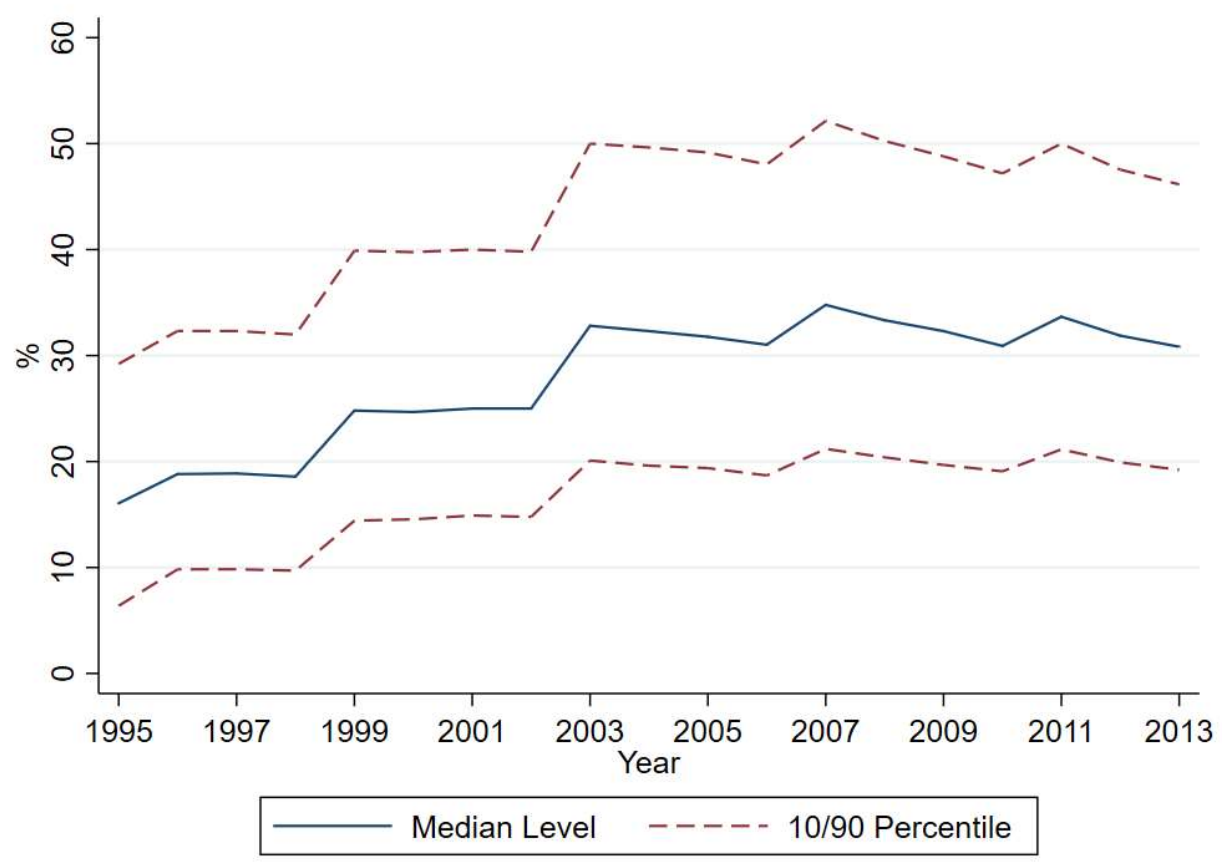

Notes: The figure plots the share of city employees with party affiliation for every year between 1995 and 2013 . The share is created by combining public employment records from RAIS with party affiliation data using a matching on person's name. See Section 4.2 for a detailed description of the matching procedure. 
Figure 2: Share of Public Employees Affiliated with a Party by City and by 1995 Quintile Thresholds

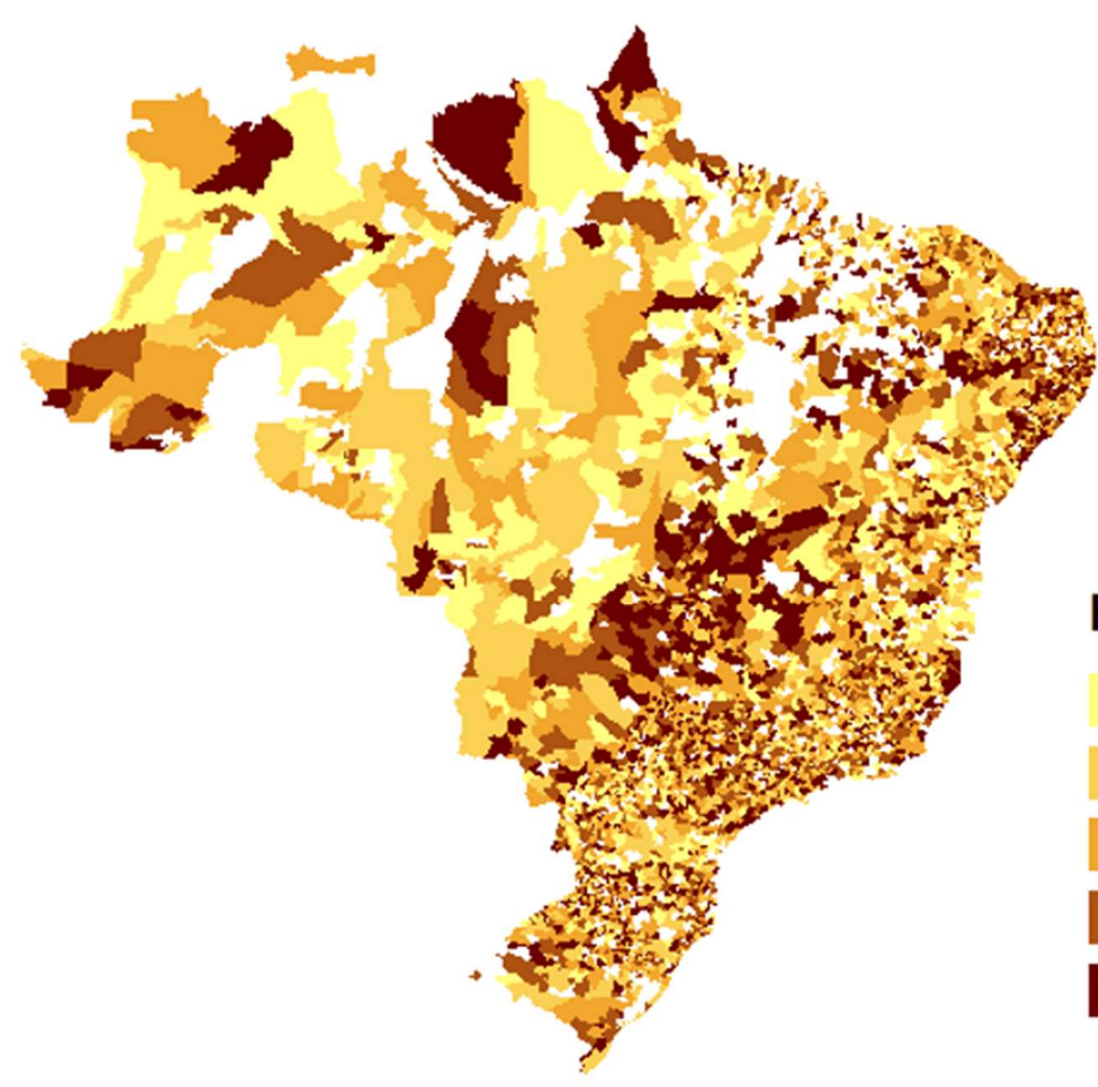

1995

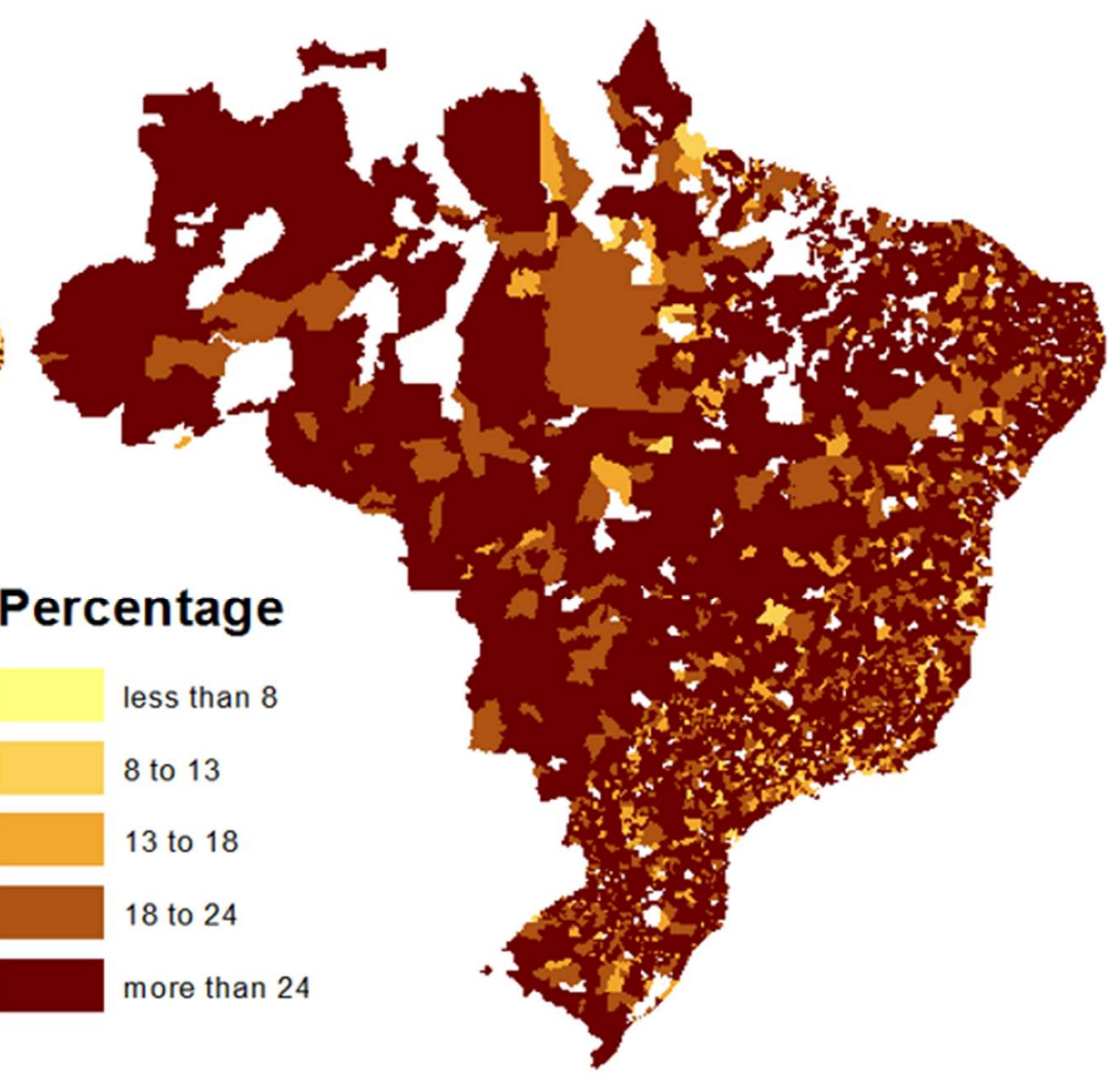

2013

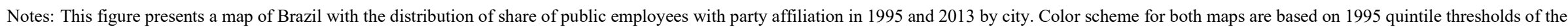
share of public employees with party affiliation, holding constant the 1995-quintile thresholds for the shares in 2013. Cities without data as displayed in white. 
Figure 3. Coalition Characteristics Around Margin of Victory Threshold
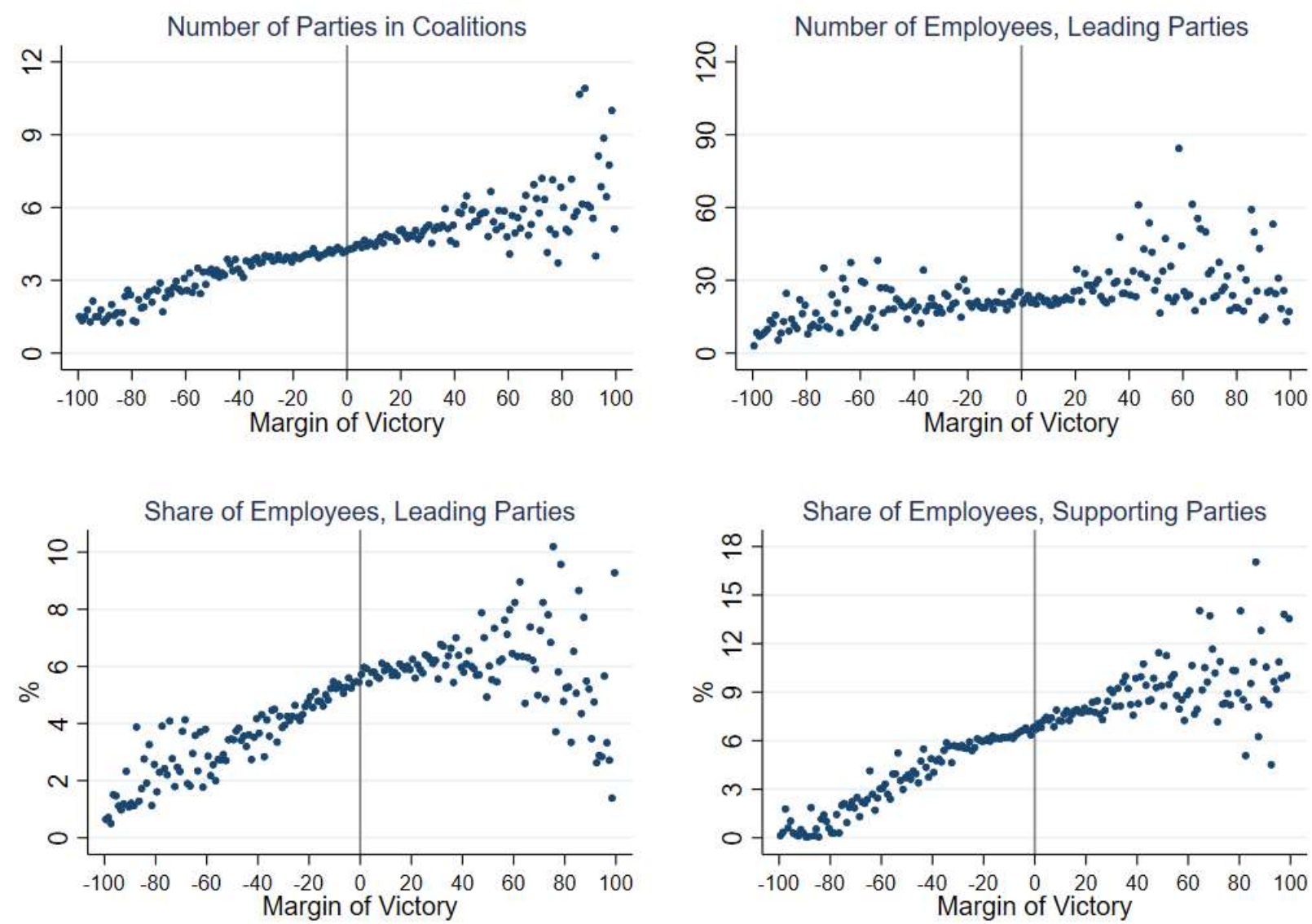

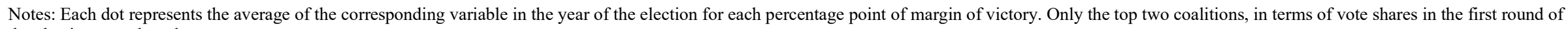
the election, are plotted. 
Figure 4: Pre-Trends in Share of Public Employees and Wages of Leading Parties

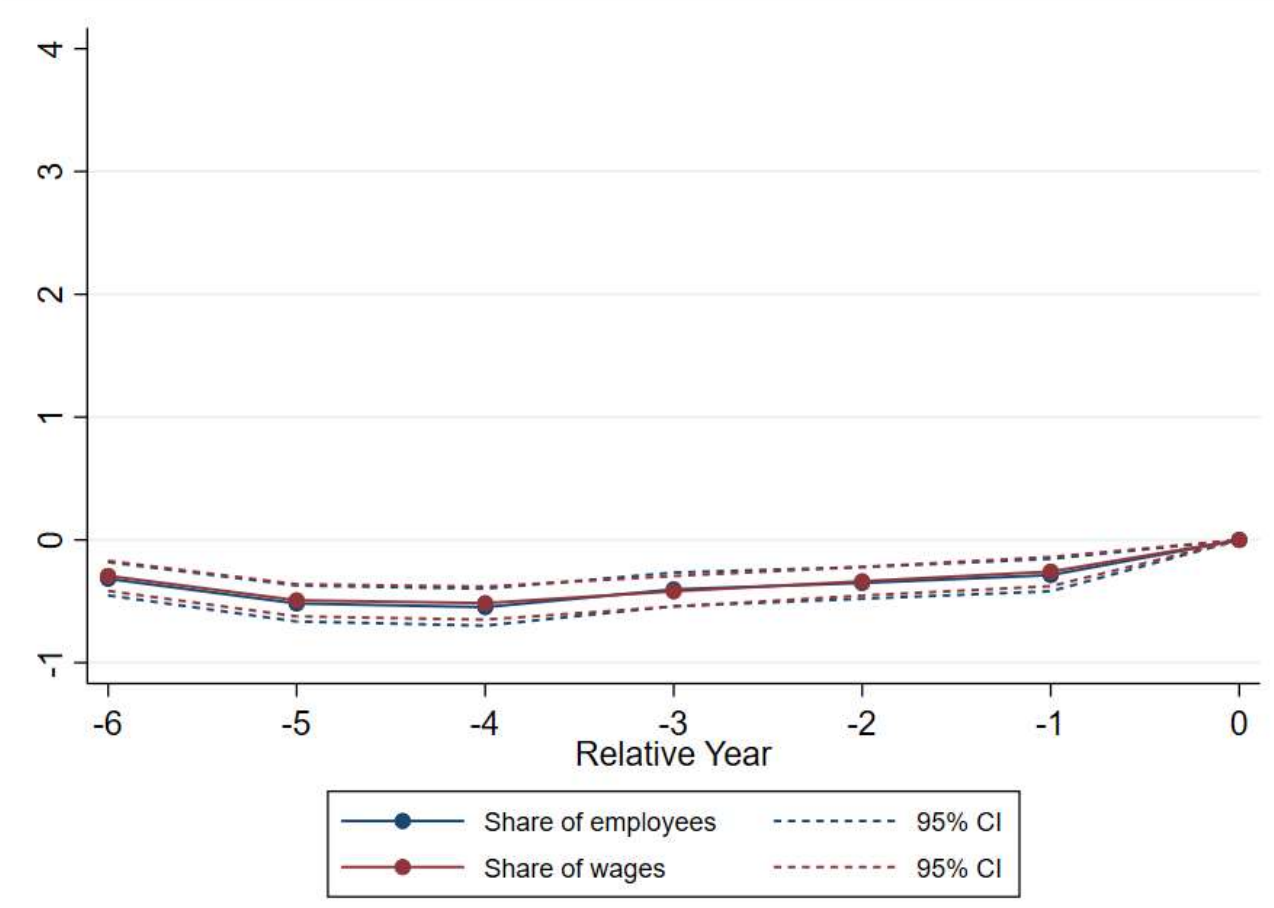

Notes: Figure plots the trend of corresponding variables for years before the election year. The relative year - 6 combines the trends for observations that are more than 5 years prior to the election. 
Figure 5: Dynamic RD Patronage Effects on the Total Number of Public Employees Affiliated with Winning Coalitions

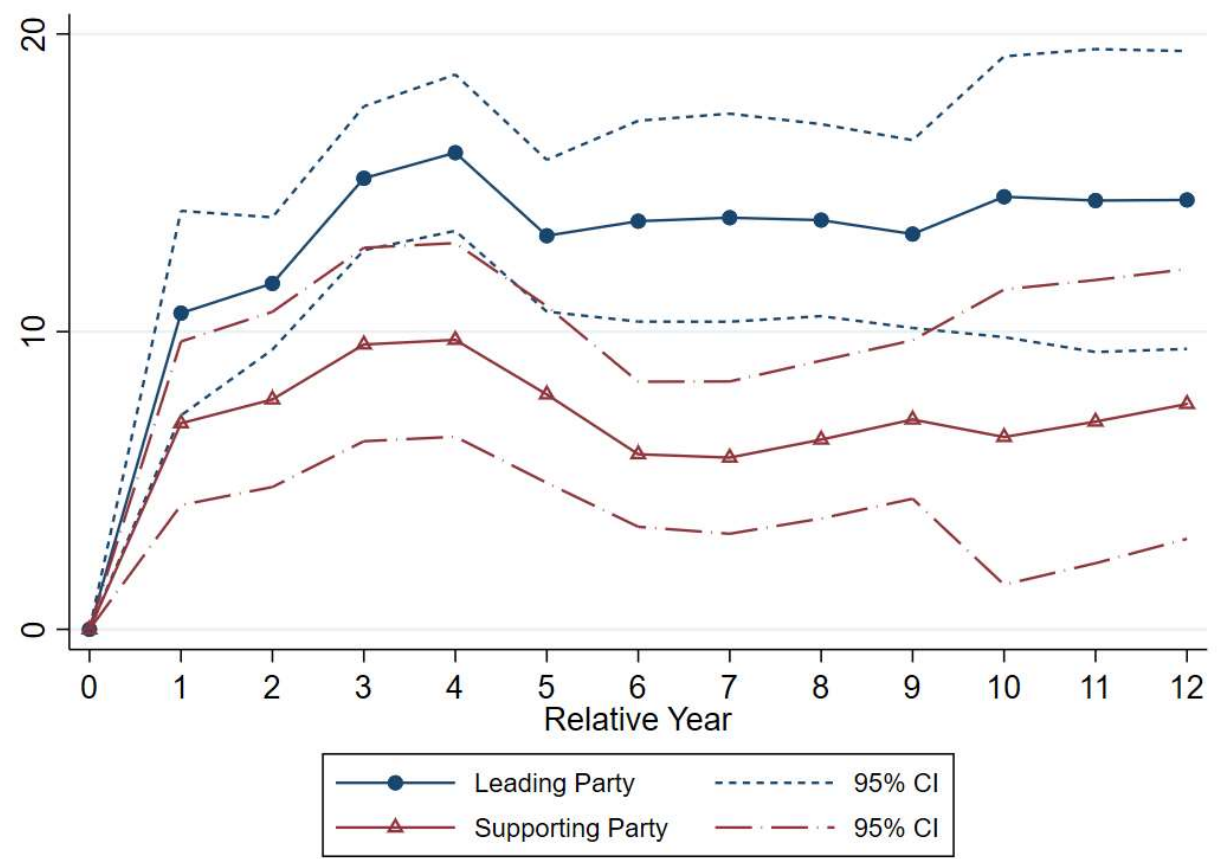

Notes: Figure plots the estimated patronage coefficients and 95 percent confidence intervals reported in columns (5) and (6) of Table 4.

Figure 6: Dynamic RD Patronage Effects on the Share of Public Employees Affiliated with Winning Coalition Parties

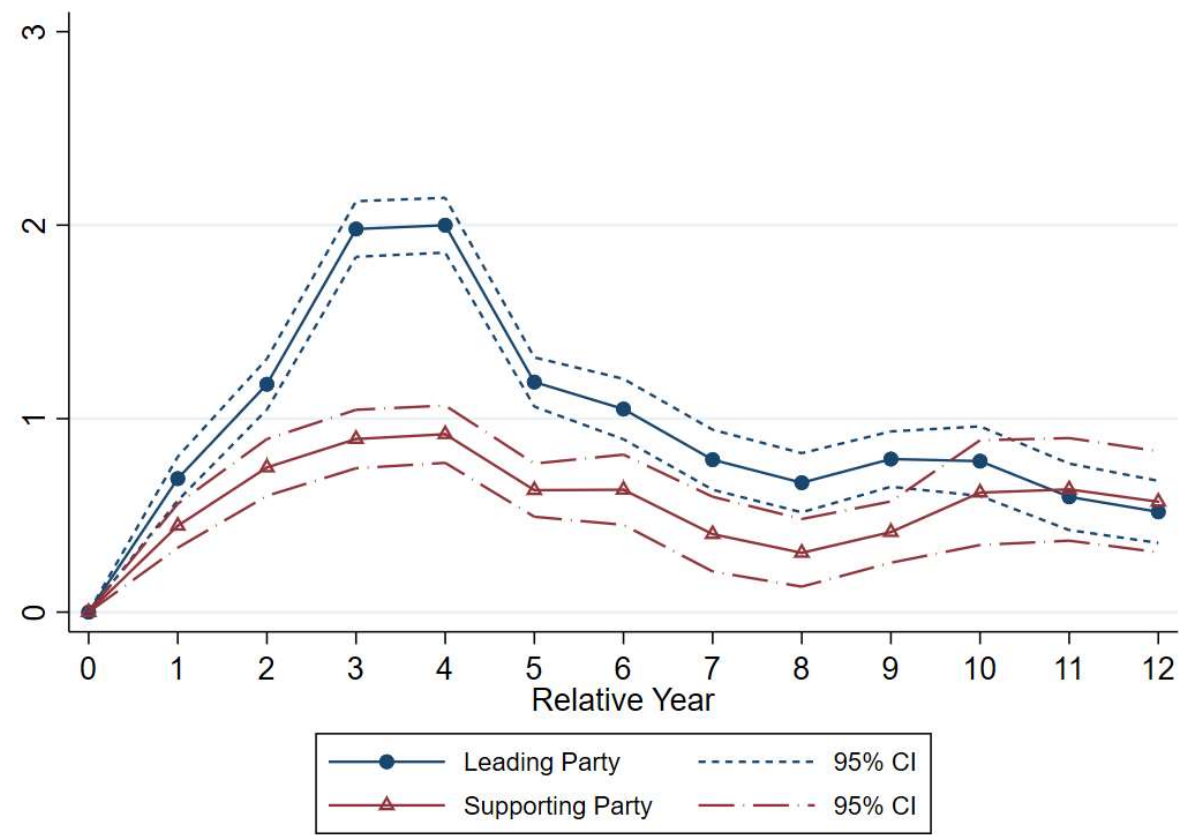

Notes: Figure plots the estimated patronage coefficients and 95 percent confidence intervals reported in columns (5) and (6) of Table 5. 
Figure 7: Dynamic RD Patronage Effects on the Share of Total Wages of Public Employees Affiliated with Winning Coalition Parties

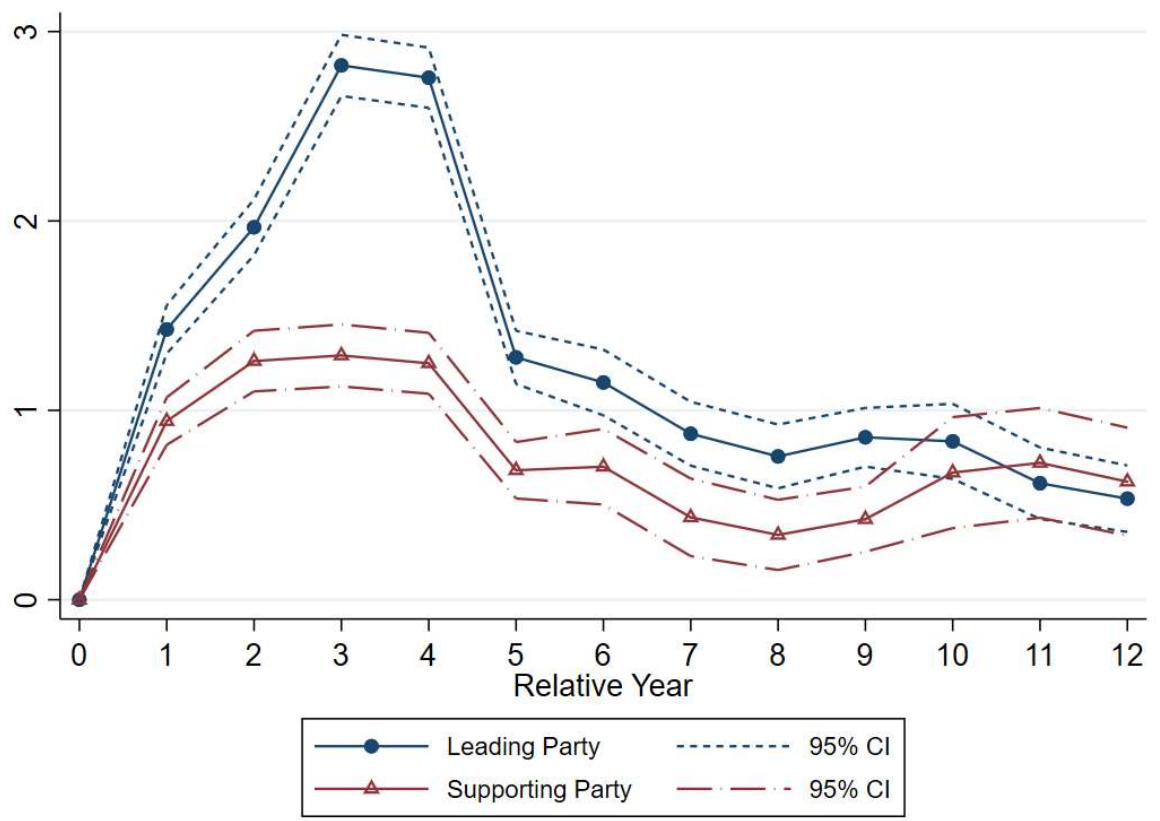

Notes: Figure plots the estimated patronage coefficients and 95 percent confidence intervals reported in columns (5) and (6) of Table 6.

Figure 8: Dynamic RD Patronage Effects on Wage Shares by Type of Occupation

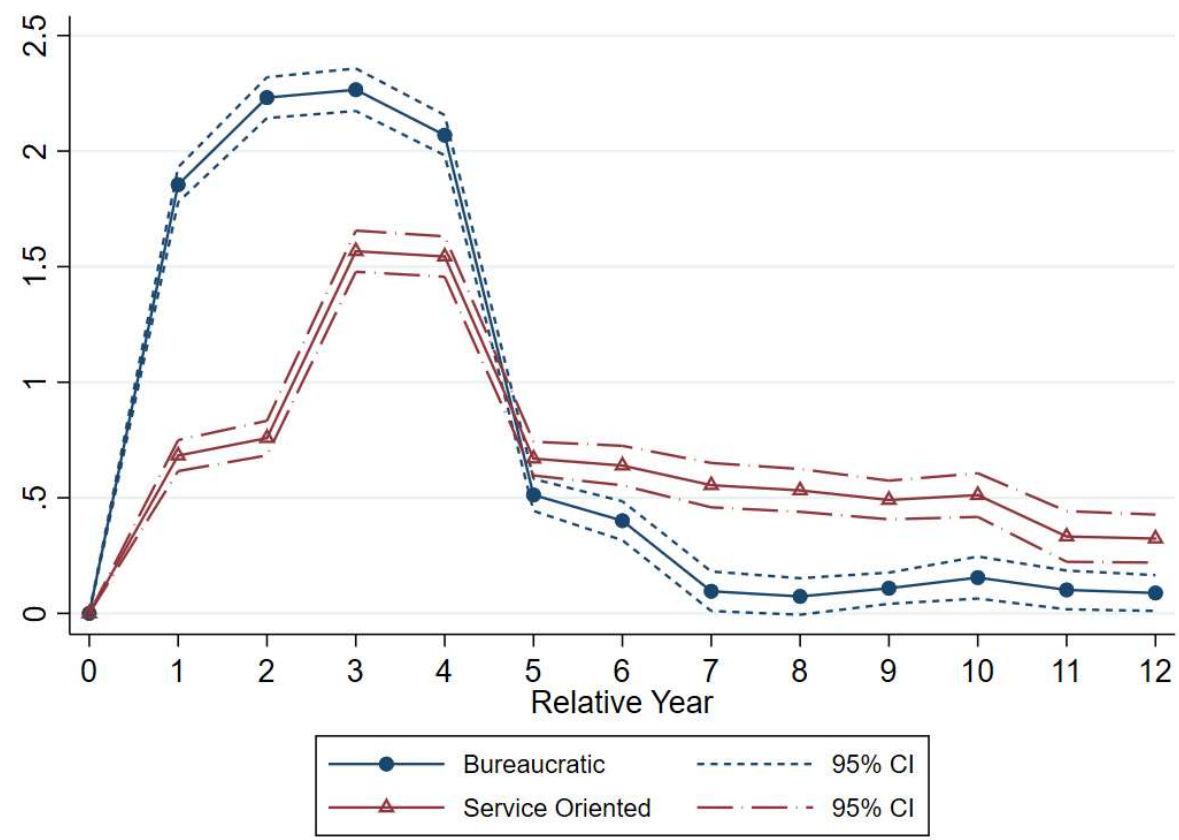

Notes: Figure plots the estimated patronage coefficients and 95 percent confidence intervals reported in columns (1) and (3) of Table 8. 
Figure 9: Differential Patronage Effects at Population Thresholds of Intergovernmental Transfers

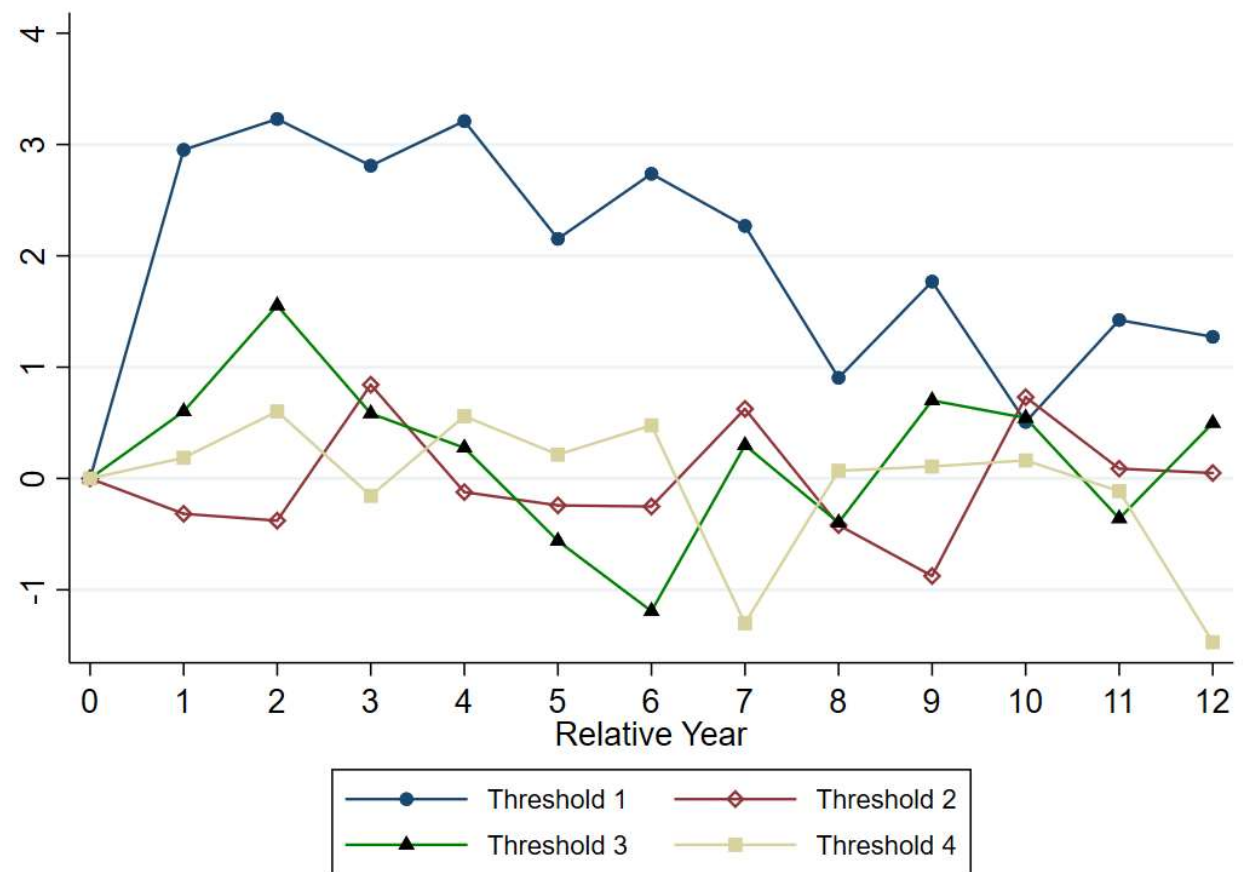

Notes: Figure plots the estimated coefficients for leading parties of the winning coalitions in cities with population within $2 \%$ around 10,188 (threshold 1), 13,584 (threshold 2), 16,980 (threshold 3), and 23,772 (threshold 4) inhabitants, comparing cities that receive more or less transfers. 
Figure 10: Accountability Channels: Effect on Patronage Share of Total Wages

\section{A. City Size Interactions}

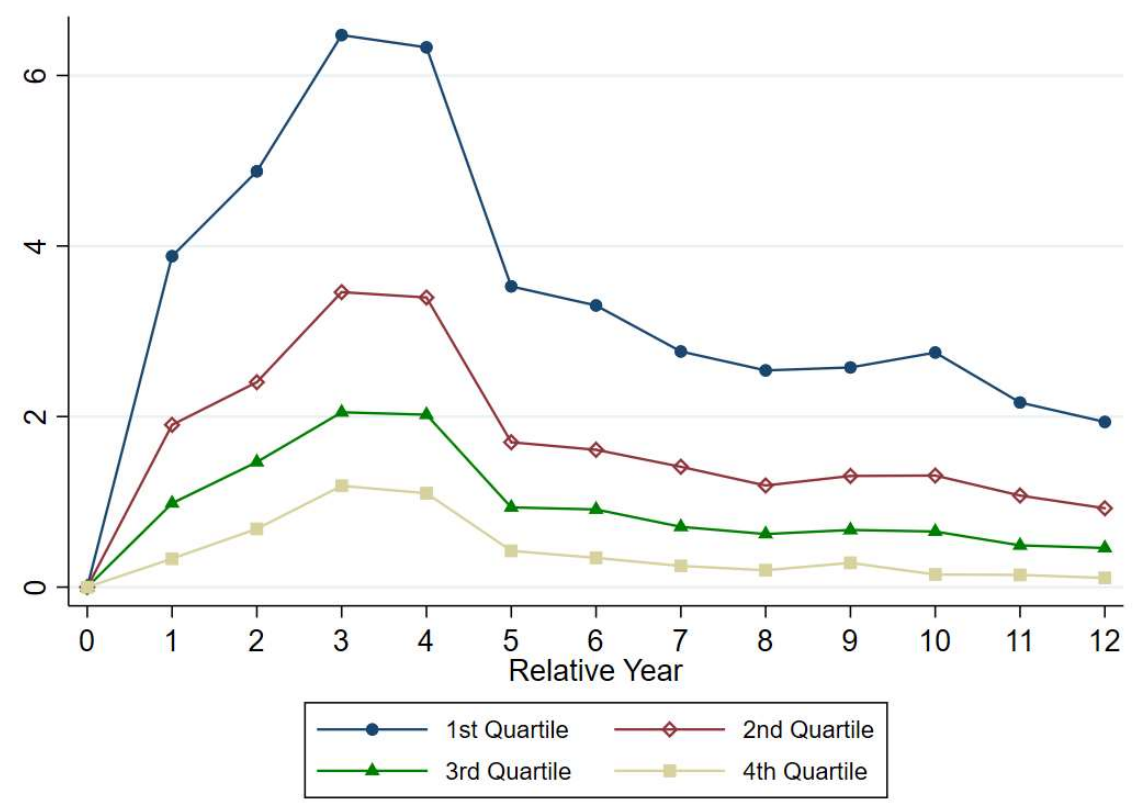

Notes: Figure plots the estimated coefficients for leading parties of the winning coalitions in cities with different sizes. Cities are classified into different groups (time invariant) based on its average population between 1995 and 2013.

\section{B. Media Interactions}
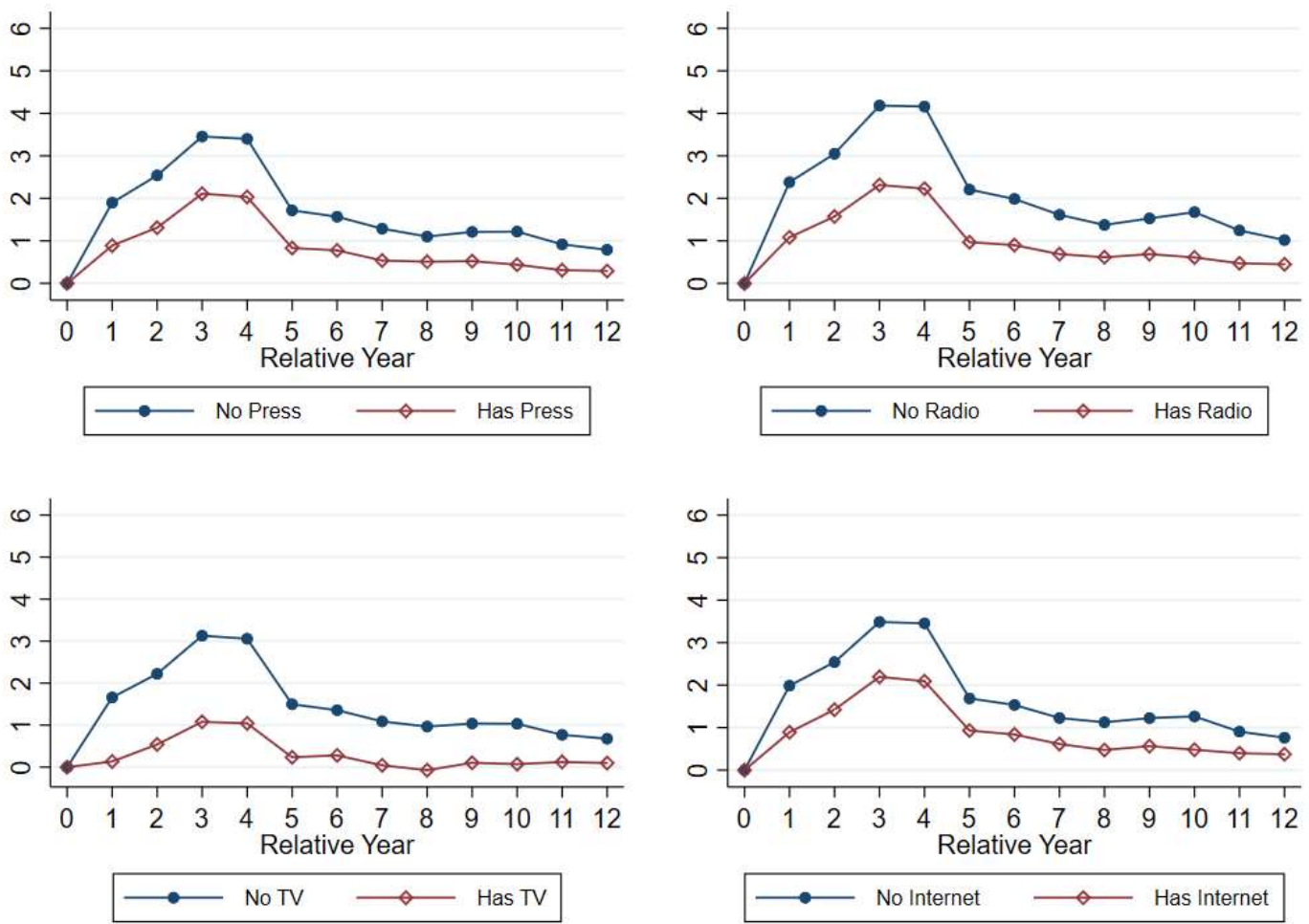

Notes: Figure plots the estimated coefficients for leading parties of the winning coalitions in cities with or without certain type of media. Each city is assigned a time invariant dummy for a given type of media based on data from a survey by the Brazilian Institute of Geography and Statistics. 


\section{Audit Interactions}

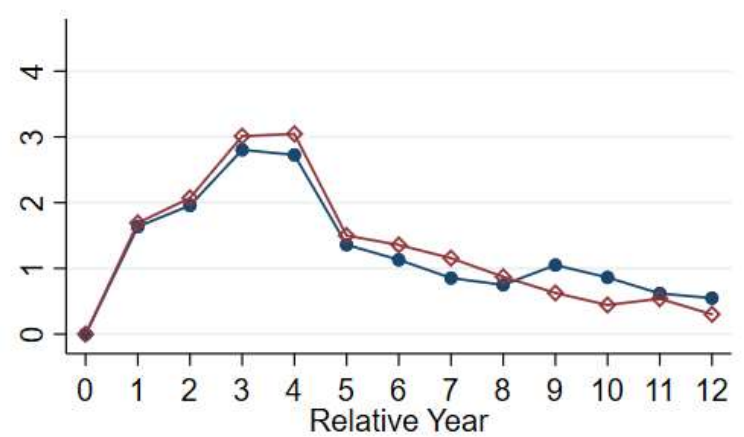

Audit Next Cycle $\longrightarrow$ No $\longrightarrow$ Yes

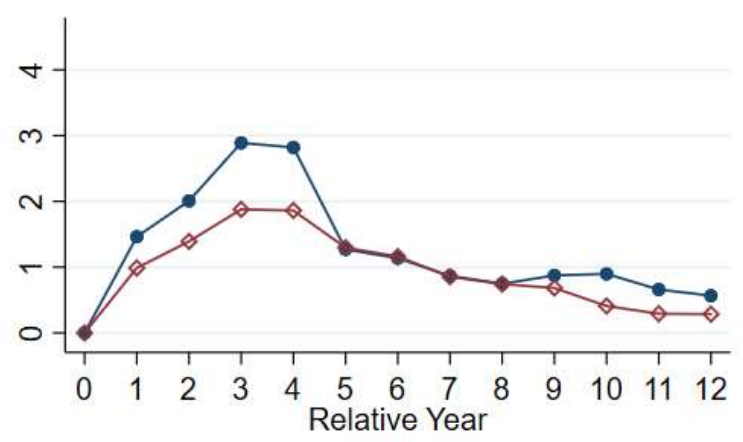

Audit Last Cycle $\longrightarrow$ No $\longrightarrow$ Yes

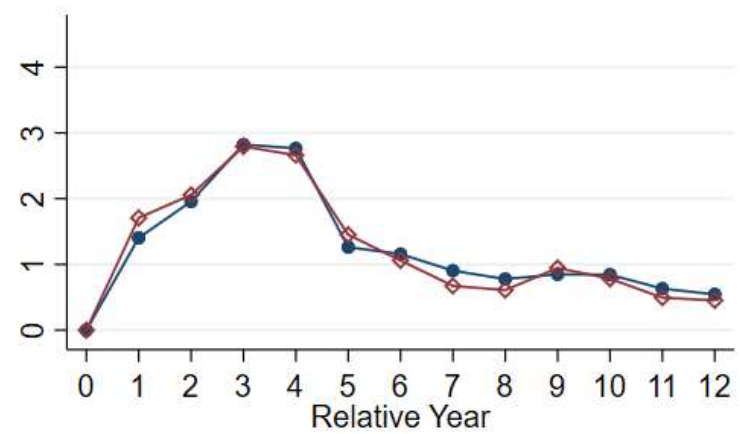

Audit Current Cycle $\longrightarrow$ No $\longrightarrow$ Yes

Notes: Figure plots the estimated coefficients for leading parties of the winning coalitions in cities with or without an audit in the next, current or last election cycle. Each election cycle begins with the year after an election and ends with the year of another election. If an audit happens in any year in an election cycle for a given city, then the currently (previously/next) elected party experiences an audit in current (last/next) cycle. 
Figure 11: Political Economy Channels: Effect on Patronage Share of Total Wages

\section{A. Party Interactions}

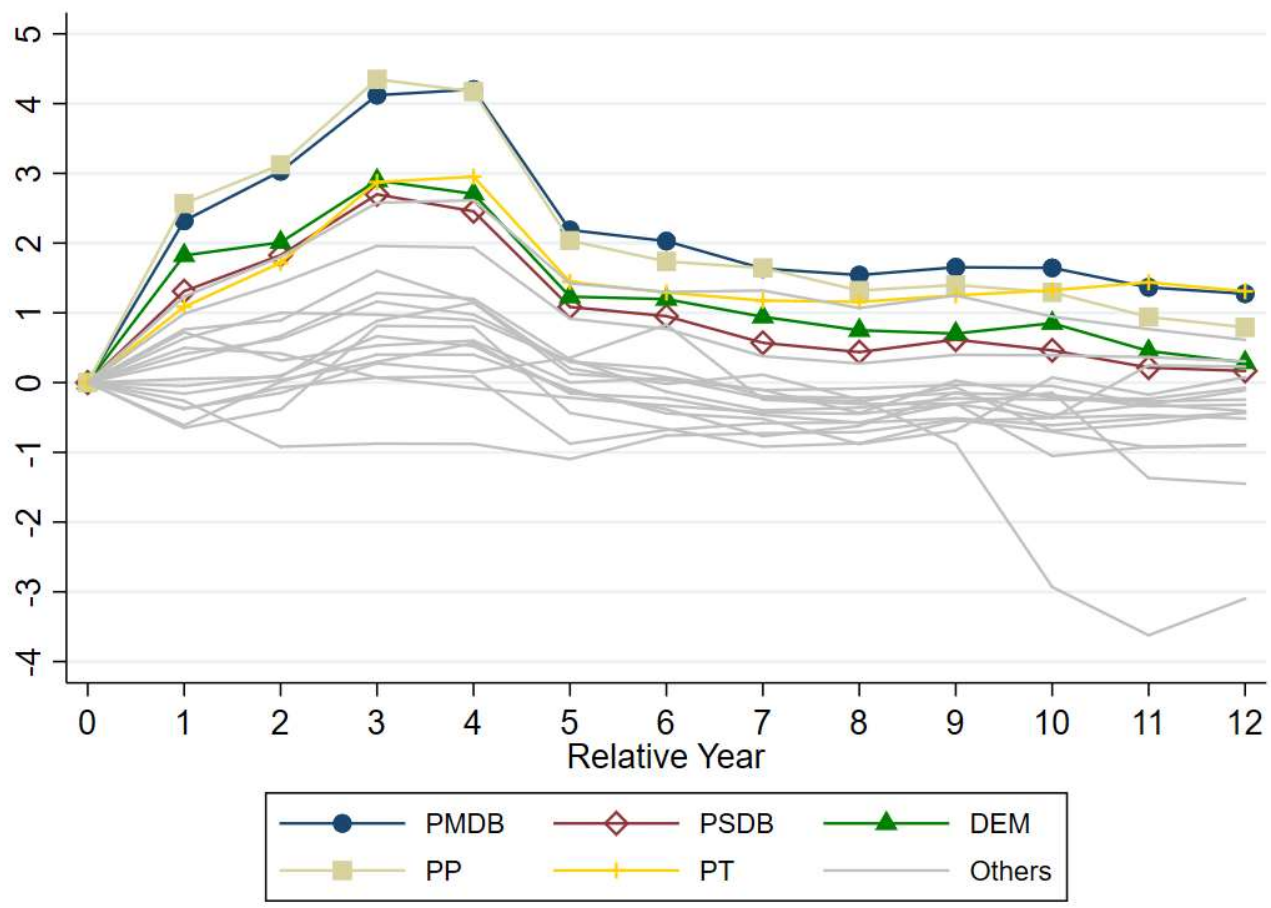

Notes: Figure plots the estimated coefficients for different parties being the leading in winning coalitions.

\section{B. Ideology Interactions}

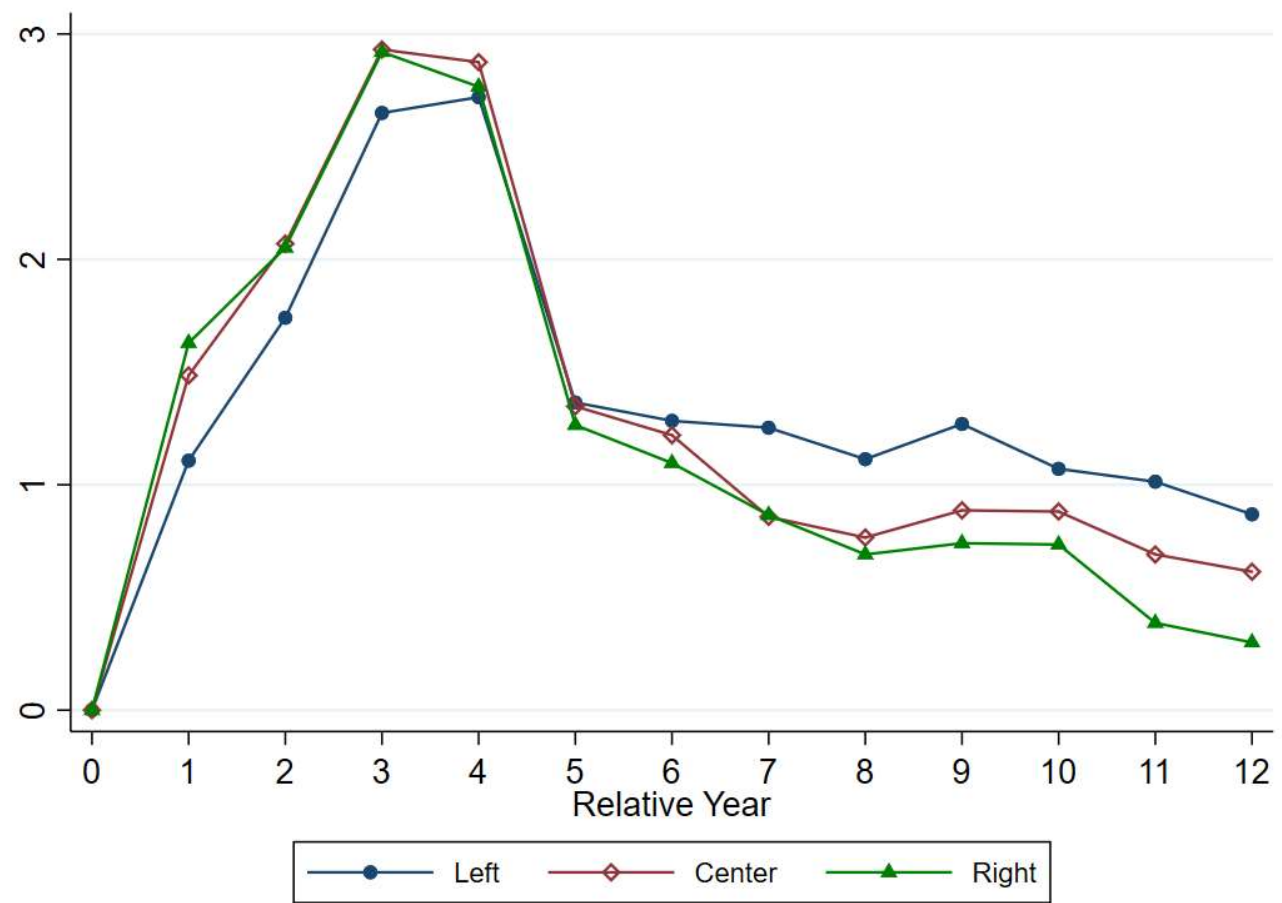

Notes: Figure plots the estimated coefficients for parties with different type of ideology that leads the winning coalitions. The ideology is based on Power and Zucco $(2009,2012,2019)$ and remain constant 1995 and 2013. 


\section{Party Size Interactions}

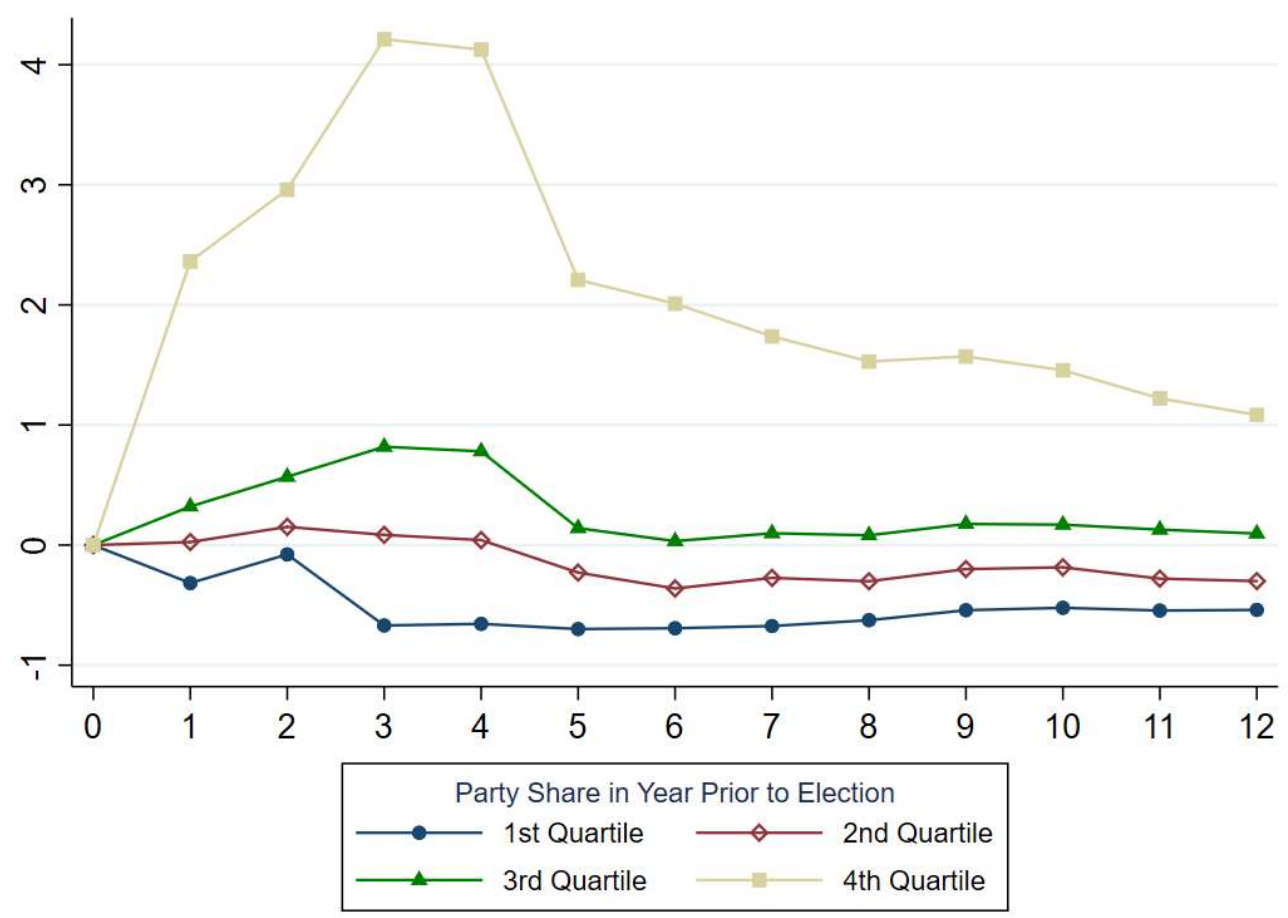

Notes: The figure plots the estimated coefficients for patronage effects for leading parties of different sizes. The size of a party is determined by its share of affiliates out of people with any party affiliation in the city for the year prior to an election. 
Figure 12: Predicted Share of Public Employees with Party Affiliation - Prediction With and Without Patronage Variables

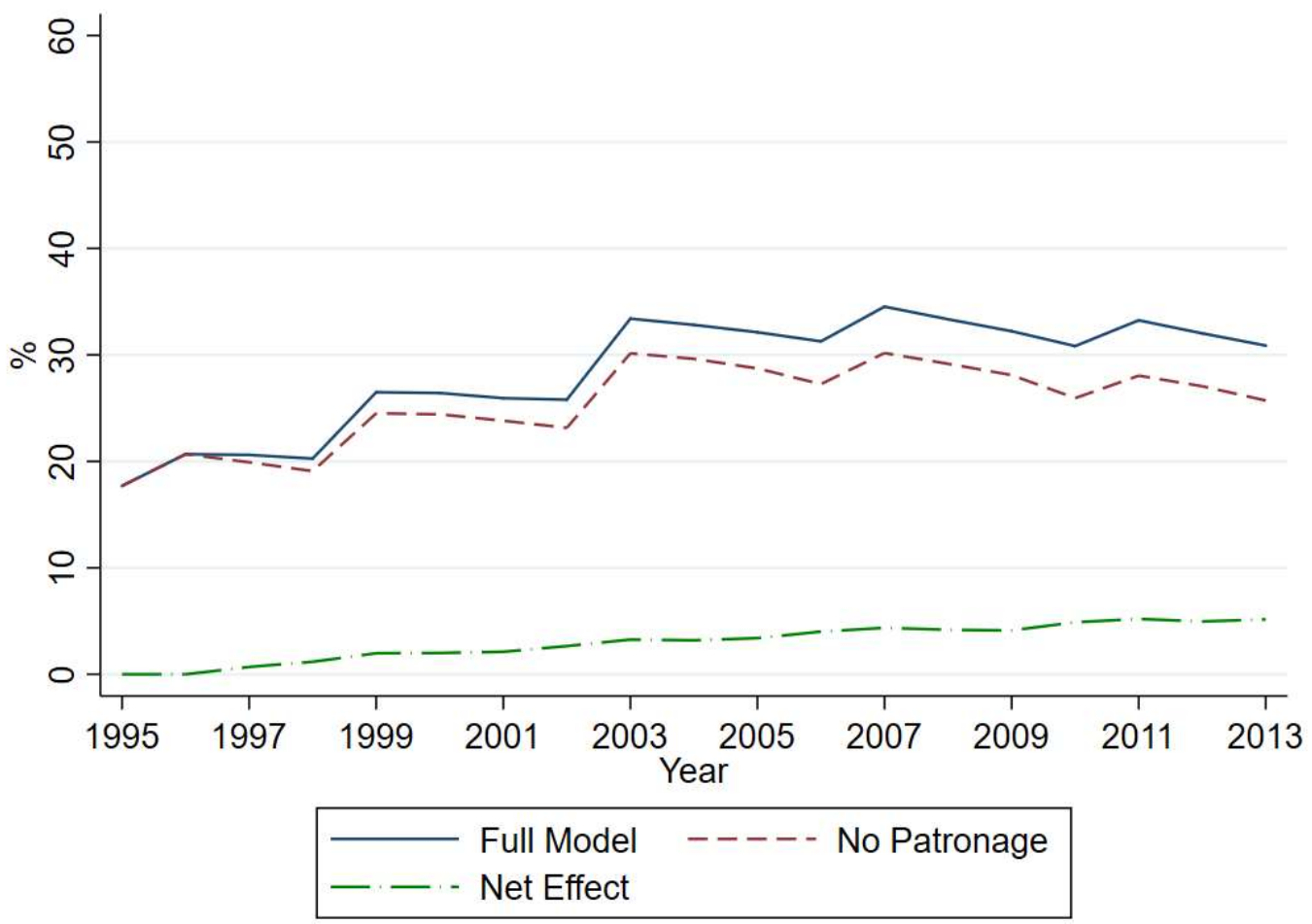

Notes: The full model refers to prediction of the regression presented in Column (5) and (6) of Table 4. No patronage refers to the prediction of the same regression but removing all patronage effect (relative year dummies). The net effect is the difference between the two predictions. 
Figure 13: Estimated Patronage Index by Municipality by Quintile

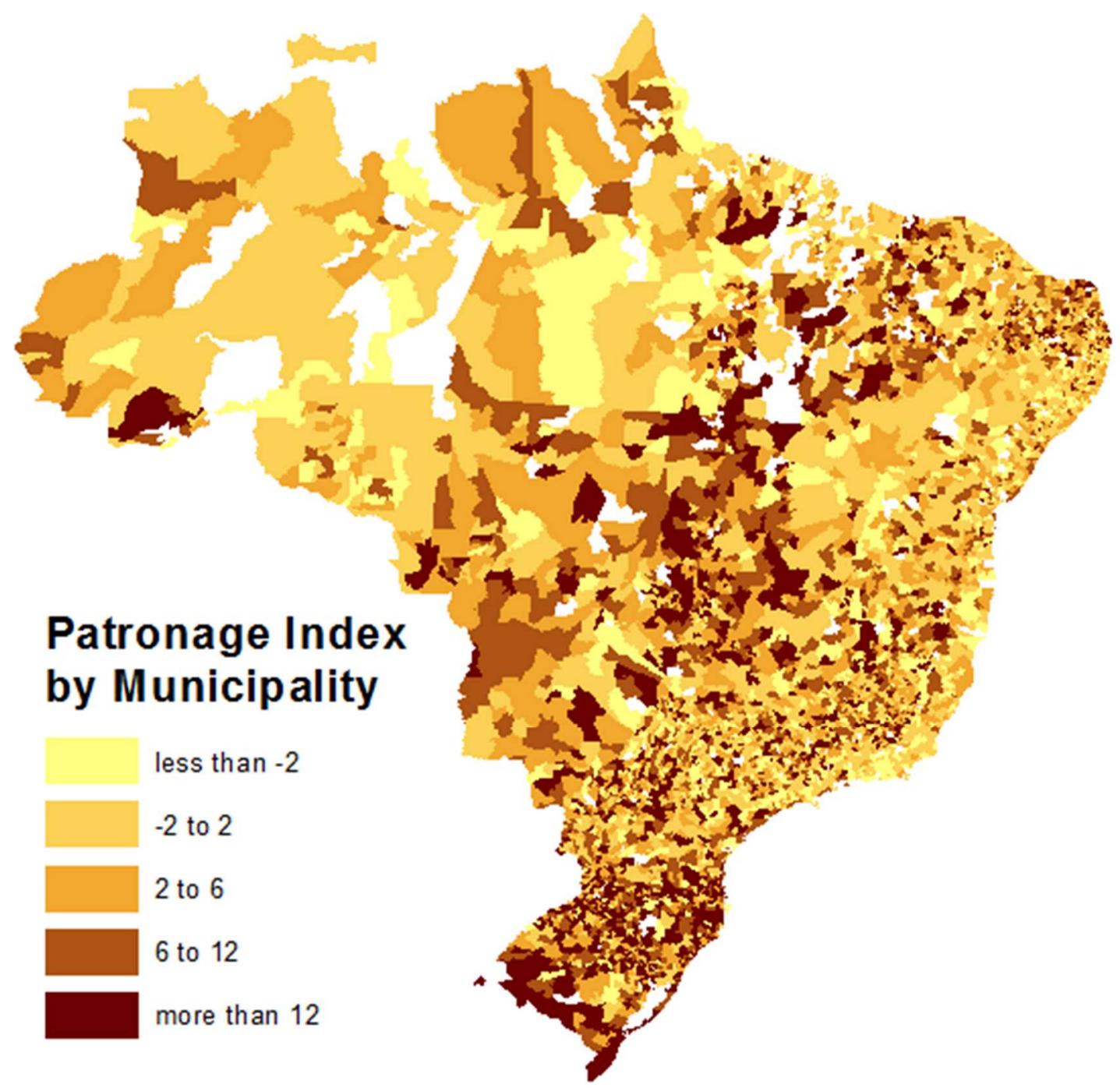

Notes: The map shows the estimated patronage effect by city in relative year 3, using the share of total wages of public employees affiliated with leading parties. Color scheme based on thresholds of quintiles of the index. White cities did not have enough data to estimate the index. 
Figure 14: Patronage Index and Affiliated Civil Servant Wage Share (IV first stage)

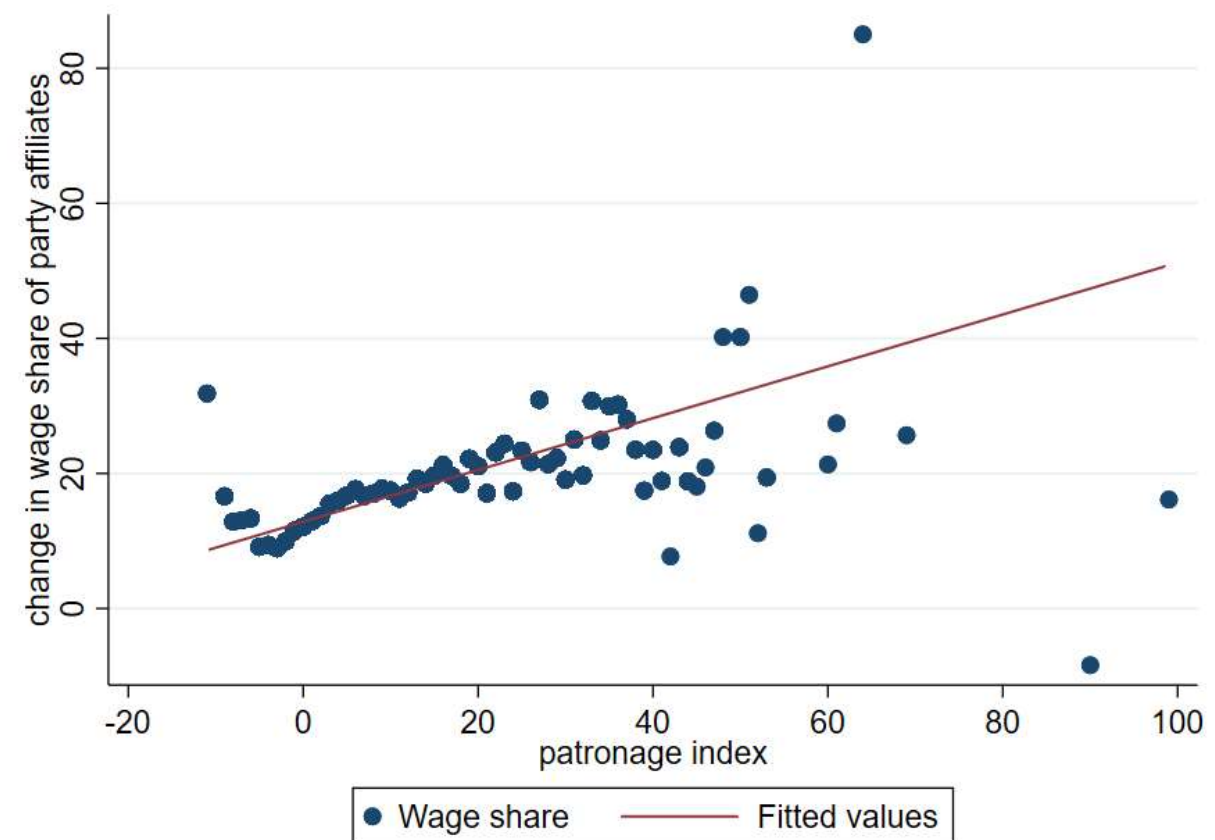

Notes: The figure plots the city-level relationship between the patronage index and change in fraction of civil servant wages going to affiliated civil servants. For visual clarity, index is rounded to the nearest whole number and civil wage shares are averaged, generating on value per rounded index. The fitted values line is fitted to the full first stage regression. 
Table 1: Summary Statistics by City-Year

\begin{tabular}{lcccccc}
\hline & Mean & SD & Min. & Median & Max. & No. \\
& $(1)$ & $(2)$ & $(3)$ & $(4)$ & $(5)$ & $(6)$ \\
\hline Panel A - RAIS Employer-Employee & & & & & & \\
Number of Public Employees & 620.9 & $2,378.8$ & 1.0 & 271.0 & 151,987 & 99,928 \\
Number of Public Employees with Party & 150.0 & 493.5 & 0.0 & 81.0 & 34,391 & 99,928 \\
Share of Public Employees with Party (\%) & 29.1 & 12.4 & 0.0 & 27.8 & 100 & 99,928 \\
Share of Wages to Public Employees with Party (\%) & 30.9 & 12.8 & 0.0 & 29.8 & 100 & 99,921 \\
Share that are Bureaucratic (\%) & 38.2 & 19.8 & 0.0 & 36.2 & 100 & 99,928 \\
Share that are Bureaucrats with Party (\%) & 11.6 & 8.5 & 0.0 & 9.8 & 100 & 99,928 \\
Share that are Service Oriented (\%) & 55.5 & 19.3 & 0.0 & 56.7 & 100 & 99,928 \\
Share that are Service Oriented with Party (\%) & 15.7 & 9.2 & 0.0 & 14.6 & 100 & 99,928 \\
Share that are Public Teachers (\%) & 25.3 & 14.0 & 0.0 & 24.7 & 100 & 99,928 \\
Share that are Teachers with Party (\%) & 5.8 & 4.9 & 0.0 & 4.9 & 100 & 99,928 \\
Share that are Public Doctors (\%) & 0.8 & 1.6 & 0.0 & 0.2 & 100 & 99,928 \\
Share that are Doctors with Party (\%) & 0.1 & 0.3 & 0.0 & 0.0 & 20 & 99,928 \\
& & & & & & \\
Panel B - Party Affiliation & & & & & & \\
Number of Parties & 11.95 & 5.94 & 0.0 & 11.00 & 32.00 & 99,928 \\
Number of Party Members & $2,045.68$ & $8,497.77$ & 0 & 891 & 544,651 & 99,928 \\
& & & & & &
\end{tabular}


Table 2: Summary Statistics of the Elections Data

\begin{tabular}{|c|c|c|c|c|c|c|}
\hline & $\begin{array}{c}\text { Mean } \\
\text { (1) }\end{array}$ & $\begin{array}{l}\text { SD } \\
\text { (2) }\end{array}$ & $\begin{array}{c}\text { Min. } \\
\text { (3) }\end{array}$ & $\begin{array}{c}\text { Median } \\
\text { (4) }\end{array}$ & $\begin{array}{c}\text { Max. } \\
(5)\end{array}$ & $\begin{array}{l}\text { No. } \\
\text { (6) }\end{array}$ \\
\hline Number of Candidates & 2.83 & 1.17 & 1 & 3 & 16 & 26,058 \\
\hline Average Number of Parties in Each Coalition & 3.27 & 2.66 & 1 & 2 & 23 & 73,811 \\
\hline Vote Share of the First Coalition (\%) & 55.40 & 12.61 & 22.72 & 53.62 & 100 & 26,058 \\
\hline Vote Share of the Second Coalition (\%) & 38.85 & 8.47 & 0.02 & 40.67 & 50 & 25,233 \\
\hline Vote Share of the Third Coalition (\%) & 12.11 & 9.13 & 0.01 & 10.50 & 33 & 12,401 \\
\hline Mayor Re-elected (\%) & 31.10 & 46.29 & 0 & 0 & 100 & 20,433 \\
\hline Leading Party Re-elected (\%) & 32.85 & 46.97 & 0 & 0 & 100 & 20,433 \\
\hline
\end{tabular}


Table 3: Summary Statistics for Estimation Sample, Party-City-Year Level Data

\begin{tabular}{lcccccc}
\hline & Mean & SD & Min. & Median & Max. & No. \\
& $(1)$ & $(2)$ & $(3)$ & $(4)$ & $(5)$ & $(6)$ \\
\hline Panel A - RAIS Employer-Employee & & & & & & \\
Public Employees with Party Affiliation & 4.51 & 31.87 & 0.00 & 0.00 & 7886.00 & 3297624 \\
Share of Public Employees with Party (\%) & 0.88 & 2.47 & 0.00 & 0.00 & 100.00 & 3297624 \\
Share Wages of Public Employees with Party (\%) & 0.93 & 2.71 & 0.00 & 0.00 & 100.00 & 3297624 \\
Share that are Bureaucratic (\%) & 0.35 & 1.25 & 0.00 & 0.00 & 100.00 & 3297624 \\
Share that are Service Oriented (\%) & 0.48 & 1.45 & 0.00 & 0.00 & 100.00 & 3297624 \\
Share that are teachers (\%) & 0.18 & 0.64 & 0.00 & 0.00 & 100.00 & 3297624 \\
Share that are doctors (\%) & 0.00 & 0.05 & 0.00 & 0.00 & 16.67 & 3297624 \\
& & & & & & \\
Panel B - Party Affiliation & & & & & & \\
Number of Party Affiliates & 61.64 & 550.66 & 0.00 & 0.00 & 129697.00 & 3297624 \\
Share of Party Affiliates (\%) & 3.03 & 6.50 & 0.00 & 0.00 & 100.00 & 3297624 \\
\hline Notes: This table presents descriptive statistics by party-city-year for the estimation sample. The denominator of the variable Share of Party \\
Affiliates is anyone with a party affiliation within the city for a given year.
\end{tabular}


Table 4: Dynamic RD Effects of Winning Election on Total Number of Public Employees Affiliated with Coalition Parties

\begin{tabular}{|c|c|c|c|c|c|c|}
\hline Winning Coalition & $\begin{array}{c}\text { Leading } \\
(1)\end{array}$ & $\begin{array}{c}\text { Supporting } \\
\text { (2) }\end{array}$ & $\begin{array}{c}\text { Leading } \\
(3)\end{array}$ & $\begin{array}{c}\text { Supporting } \\
\text { (4) }\end{array}$ & $\begin{array}{c}\text { Leading } \\
(5)\end{array}$ & $\begin{array}{c}\text { Supporting } \\
(6)\end{array}$ \\
\hline Relative Year: +1 & $\begin{array}{c}14.727 * * * \\
(0.561)\end{array}$ & $\begin{array}{c}5.958 * * * \\
(0.200)\end{array}$ & $\begin{array}{c}11.490 * * * \\
(1.806)\end{array}$ & $\begin{array}{c}3.294 * * * \\
(0.595)\end{array}$ & $\begin{array}{c}10.621 * * * \\
(1.753)\end{array}$ & $\begin{array}{c}2.097 * * * \\
(0.425)\end{array}$ \\
\hline Relative Year: +2 & $\begin{array}{c}16.036^{* * * *} \\
(0.448)\end{array}$ & $\begin{array}{c}6.661 * * * \\
(0.189)\end{array}$ & $\begin{array}{c}12.362 * * * \\
(1.194)\end{array}$ & $\begin{array}{c}3.245 * * * \\
(0.571)\end{array}$ & $\begin{array}{c}11.619 * * * \\
(1.134)\end{array}$ & $\begin{array}{c}2.340 * * * \\
(0.455)\end{array}$ \\
\hline Relative Year: +3 & $\begin{array}{c}19.946 * * * \\
(0.501)\end{array}$ & $\begin{array}{c}7.993 * * * \\
(0.208)\end{array}$ & $\begin{array}{c}15.895 * * * \\
(1.290)\end{array}$ & $\begin{array}{c}3.806 * * * \\
(0.626)\end{array}$ & $\begin{array}{c}15.152 * * * \\
(1.233)\end{array}$ & $\begin{array}{c}2.899 * * * \\
(0.502)\end{array}$ \\
\hline Relative Year: +4 & $\begin{array}{c}20.650 * * * \\
(0.554)\end{array}$ & $\begin{array}{c}8.044 * * * \\
(0.206)\end{array}$ & $\begin{array}{c}16.775 * * * \\
(1.395)\end{array}$ & $\begin{array}{c}3.881 * * * \\
(0.636)\end{array}$ & $\begin{array}{c}16.012 * * * \\
(1.339)\end{array}$ & $\begin{array}{c}2.946^{* * * *} \\
(0.503)\end{array}$ \\
\hline Relative Year: +5 & $\begin{array}{c}15.291 * * * \\
(0.419)\end{array}$ & $\begin{array}{c}5.911 * * * \\
(0.168)\end{array}$ & $\begin{array}{c}13.547 * * * \\
(1.312)\end{array}$ & $\begin{array}{c}3.201 * * * \\
(0.580)\end{array}$ & $\begin{array}{c}13.223 * * * \\
(1.300)\end{array}$ & $\begin{array}{c}2.390 * * * \\
(0.459)\end{array}$ \\
\hline Relative Year: +6 & $\begin{array}{c}15.257 * * * \\
(0.578)\end{array}$ & $\begin{array}{c}6.724 * * * \\
(0.228)\end{array}$ & $\begin{array}{c}13.894 * * * \\
(1.656)\end{array}$ & $\begin{array}{c}2.861 * * * \\
(0.495)\end{array}$ & $\begin{array}{c}13.711 * * * \\
(1.721)\end{array}$ & $\begin{array}{c}1.782 * * * \\
(0.377)\end{array}$ \\
\hline Relative Year: +7 & $\begin{array}{c}15.335 * * * \\
(0.601)\end{array}$ & $\begin{array}{c}7.023 * * * \\
(0.241)\end{array}$ & $\begin{array}{c}14.012 * * * \\
(1.720)\end{array}$ & $\begin{array}{c}2.789 * * * \\
(0.527)\end{array}$ & $\begin{array}{c}13.829 * * * \\
(1.782)\end{array}$ & $\begin{array}{c}1.748 * * * \\
(0.395)\end{array}$ \\
\hline Relative Year: +8 & $\begin{array}{c}15.201 * * * \\
(0.544)\end{array}$ & $\begin{array}{c}6.923 * * * \\
(0.247)\end{array}$ & $\begin{array}{c}13.925 * * * \\
(1.591)\end{array}$ & $\begin{array}{c}2.985 * * * \\
(0.555)\end{array}$ & $\begin{array}{c}13.747 * * * \\
(1.645)\end{array}$ & $\begin{array}{c}1.931^{* * * *} \\
(0.410)\end{array}$ \\
\hline Relative Year: +9 & $\begin{array}{c}14.017 * * * \\
(0.573)\end{array}$ & $\begin{array}{c}5.947 * * * \\
(0.235)\end{array}$ & $\begin{array}{c}13.438 * * * \\
(1.544)\end{array}$ & $\begin{array}{c}3.065 * * * \\
(0.565)\end{array}$ & $\begin{array}{c}13.278 * * * \\
(1.609)\end{array}$ & $\begin{array}{c}2.135^{* * *} \\
(0.411)\end{array}$ \\
\hline Relative Year: +10 & $\begin{array}{c}14.464 * * * \\
(0.743)\end{array}$ & $\begin{array}{c}7.503 * * * \\
(0.345)\end{array}$ & $\begin{array}{c}14.970 * * * \\
(2.417)\end{array}$ & $\begin{array}{c}4.317 * * * \\
(0.982)\end{array}$ & $\begin{array}{c}14.531 * * * \\
(2.406)\end{array}$ & $\begin{array}{l}1.957^{*} \\
(0.766)\end{array}$ \\
\hline Relative Year: +11 & $\begin{array}{c}14.029 * * * \\
(0.790)\end{array}$ & $\begin{array}{c}7.699 * * * \\
(0.351)\end{array}$ & $\begin{array}{c}14.828 * * * \\
(2.606)\end{array}$ & $\begin{array}{c}4.487 * * * \\
(1.058)\end{array}$ & $\begin{array}{c}14.404 * * * \\
(2.595)\end{array}$ & $\begin{array}{l}2.114 * * \\
(0.735)\end{array}$ \\
\hline Relative Year: +12 & $\begin{array}{c}13.759 * * * \\
(0.779)\end{array}$ & $\begin{array}{c}7.155 * * * \\
(0.336)\end{array}$ & $\begin{array}{c}14.854 * * * \\
(2.563)\end{array}$ & $\begin{array}{c}4.684 * * * \\
(1.064)\end{array}$ & $\begin{array}{c}14.424 * * * \\
(2.552)\end{array}$ & $\begin{array}{l}2.293 * * \\
(0.700)\end{array}$ \\
\hline Vote Share & \multicolumn{2}{|c|}{$\mathrm{N}$} & \multicolumn{2}{|l|}{ ( } & \multicolumn{2}{|c|}{$\mathrm{Y}$} \\
\hline Leading/Supporting Party & \multicolumn{2}{|c|}{$\mathrm{N}$} & \multicolumn{2}{|c|}{$\mathrm{Y}$} & \multicolumn{2}{|c|}{$\mathrm{Y}$} \\
\hline Leading X Vote Share & \multicolumn{2}{|c|}{$\mathrm{N}$} & \multicolumn{2}{|c|}{$\mathrm{Y}$} & \multicolumn{2}{|c|}{$\mathrm{Y}$} \\
\hline City, Year, Party FE & \multicolumn{2}{|c|}{$\mathrm{N}$} & \multicolumn{2}{|c|}{$\mathrm{N}$} & \multicolumn{2}{|c|}{$\mathrm{Y}$} \\
\hline $\begin{array}{l}\text { R-sq. } \\
\text { No. Obs }\end{array}$ & \multicolumn{2}{|c|}{0.033} & \multicolumn{2}{|c|}{0.061} & \multicolumn{2}{|c|}{0.071} \\
\hline
\end{tabular}


Table 5: Dynamic RD Effects of Winning Election on the Share of Public Employees Affiliated with Coalition Parties

\begin{tabular}{|c|c|c|c|c|c|c|}
\hline Winning Coalition & $\begin{array}{l}\text { Leading } \\
\text { (1) }\end{array}$ & $\begin{array}{c}\text { Supporting } \\
\text { (2) }\end{array}$ & $\begin{array}{c}\text { Leading } \\
\text { (3) }\end{array}$ & $\begin{array}{c}\text { Supporting } \\
\text { (4) }\end{array}$ & $\begin{array}{c}\text { Leading } \\
(5)\end{array}$ & $\begin{array}{c}\text { Supporting } \\
\text { (6) }\end{array}$ \\
\hline Relative Year: +1 & $\begin{array}{c}3.944 * * * \\
(0.048)\end{array}$ & $\begin{array}{c}1.071 * * * \\
(0.014)\end{array}$ & $\begin{array}{c}0.620 * * * \\
(0.060)\end{array}$ & $\begin{array}{c}0.021 \\
(0.020)\end{array}$ & $\begin{array}{c}0.690 * * * \\
(0.058)\end{array}$ & $\begin{array}{c}0.135 * * * \\
(0.018)\end{array}$ \\
\hline Relative Year: +2 & $\begin{array}{c}4.387 * * * \\
(0.055)\end{array}$ & $\begin{array}{c}1.264 * * * \\
(0.018)\end{array}$ & $\begin{array}{c}1.085^{* * *} \\
(0.069)\end{array}$ & $\begin{array}{c}0.087 * * * \\
(0.026)\end{array}$ & $\begin{array}{c}1.178 * * * \\
(0.067)\end{array}$ & $\begin{array}{c}0.227 * * * \\
(0.023)\end{array}$ \\
\hline Relative Year: +3 & $\begin{array}{c}5.382 * * * \\
(0.064)\end{array}$ & $\begin{array}{c}1.469 * * * \\
(0.019)\end{array}$ & $\begin{array}{c}1.886^{* * *} \\
(0.075)\end{array}$ & $\begin{array}{c}0.127 * * * \\
(0.026)\end{array}$ & $\begin{array}{c}1.980 * * * \\
(0.073)\end{array}$ & $\begin{array}{c}0.271 * * * \\
(0.023)\end{array}$ \\
\hline Relative Year: +4 & $\begin{array}{c}5.293 * * * \\
(0.064)\end{array}$ & $\begin{array}{c}1.419 * * * \\
(0.018)\end{array}$ & $\begin{array}{c}1.907 * * * \\
(0.074)\end{array}$ & $\begin{array}{c}0.135 * * * \\
(0.026)\end{array}$ & $\begin{array}{c}2.000 * * * \\
(0.072)\end{array}$ & $\begin{array}{c}0.279 * * * \\
(0.023)\end{array}$ \\
\hline Relative Year: +5 & $\begin{array}{c}3.616^{* * * *} \\
(0.047)\end{array}$ & $\begin{array}{c}0.898 * * * \\
(0.014)\end{array}$ & $\begin{array}{c}1.015^{* * * *} \\
(0.067)\end{array}$ & $\begin{array}{c}0.065 * * \\
(0.024)\end{array}$ & $\begin{array}{c}1.189 * * * \\
(0.065)\end{array}$ & $\begin{array}{c}0.191 * * * \\
(0.021)\end{array}$ \\
\hline Relative Year: +6 & $\begin{array}{c}3.625^{* * *} \\
(0.052)\end{array}$ & $\begin{array}{c}0.968 * * * \\
(0.017)\end{array}$ & $\begin{array}{c}0.834 * * * \\
(0.081)\end{array}$ & $\begin{array}{c}0.037 \\
(0.031)\end{array}$ & $\begin{array}{c}1.049 * * * \\
(0.080)\end{array}$ & $\begin{array}{c}0.192^{* * *} \\
(0.028)\end{array}$ \\
\hline Relative Year: +7 & $\begin{array}{c}3.393 * * * \\
(0.051)\end{array}$ & $\begin{array}{c}0.912 * * * \\
(0.017)\end{array}$ & $\begin{array}{c}0.570 * * * \\
(0.081)\end{array}$ & $\begin{array}{l}-0.038 \\
(0.033)\end{array}$ & $\begin{array}{c}0.788 * * * \\
(0.079)\end{array}$ & $\begin{array}{c}0.122 * * * \\
(0.030)\end{array}$ \\
\hline Relative Year: +8 & $\begin{array}{c}3.196^{* * *} \\
(0.048)\end{array}$ & $\begin{array}{c}0.848 * * * \\
(0.016)\end{array}$ & $\begin{array}{c}0.452 * * * \\
(0.080)\end{array}$ & $\begin{array}{l}-0.063^{*} \\
(0.030)\end{array}$ & $\begin{array}{c}0.669 * * * \\
(0.078)\end{array}$ & $\begin{array}{c}0.093 * * * \\
(0.027)\end{array}$ \\
\hline Relative Year: +9 & $\begin{array}{c}2.796^{* * * *} \\
(0.045)\end{array}$ & $\begin{array}{c}0.544 * * * \\
(0.014)\end{array}$ & $\begin{array}{c}0.607 * * * \\
(0.074)\end{array}$ & $\begin{array}{l}-0.028 \\
(0.028)\end{array}$ & $\begin{array}{c}0.791 * * * \\
(0.073)\end{array}$ & $\begin{array}{c}0.125 * * * \\
(0.024)\end{array}$ \\
\hline Relative Year: +10 & $\begin{array}{c}2.859 * * * \\
(0.051)\end{array}$ & $\begin{array}{c}0.649 * * * \\
(0.023)\end{array}$ & $\begin{array}{c}0.629 * * * \\
(0.094)\end{array}$ & $\begin{array}{c}0.041 \\
(0.046)\end{array}$ & $\begin{array}{c}0.780 * * * \\
(0.092)\end{array}$ & $\begin{array}{c}0.187 * * * \\
(0.042)\end{array}$ \\
\hline Relative Year: +11 & $\begin{array}{c}2.535^{* * *} * \\
(0.048)\end{array}$ & $\begin{array}{c}0.567 * * * \\
(0.023)\end{array}$ & $\begin{array}{c}0.445^{* * *} \\
(0.090)\end{array}$ & $\begin{array}{c}0.045 \\
(0.046)\end{array}$ & $\begin{array}{c}0.596^{* * *} * \\
(0.088)\end{array}$ & $\begin{array}{c}0.192 * * * \\
(0.041)\end{array}$ \\
\hline Relative Year: +12 & $\begin{array}{c}2.352 * * * \\
(0.045)\end{array}$ & $\begin{array}{c}0.511 * * * \\
(0.022)\end{array}$ & $\begin{array}{c}0.369 * * * \\
(0.084) \\
\end{array}$ & $\begin{array}{c}0.027 \\
(0.044) \\
\end{array}$ & $\begin{array}{c}0.518^{* * *} * \\
(0.082)\end{array}$ & $\begin{array}{c}0.173 * * * \\
(0.040) \\
\end{array}$ \\
\hline Vote Share & \multicolumn{2}{|c|}{$\mathrm{N}$} & \multicolumn{2}{|c|}{$\mathrm{Y}$} & \multicolumn{2}{|c|}{$\mathrm{Y}$} \\
\hline Leading/Supporting Party & \multicolumn{2}{|c|}{$\mathrm{N}$} & \multicolumn{2}{|c|}{$\mathrm{Y}$} & \multicolumn{2}{|c|}{$\mathrm{Y}$} \\
\hline Leading X Vote Share & \multicolumn{2}{|c|}{$\mathrm{N}$} & \multicolumn{2}{|c|}{$\mathrm{Y}$} & \multicolumn{2}{|c|}{$\mathrm{Y}$} \\
\hline City, Year, Party FE & \multicolumn{2}{|c|}{$\mathrm{N}$} & \multicolumn{2}{|c|}{$\mathrm{N}$} & \multicolumn{2}{|c|}{$\mathrm{Y}$} \\
\hline $\begin{array}{l}\text { R-sq. } \\
\text { No. Obs }\end{array}$ & \multicolumn{2}{|c|}{0.256} & \multicolumn{2}{|c|}{0.317} & \multicolumn{2}{|c|}{0.422} \\
\hline
\end{tabular}


Table 6: Dynamic RD Effects of Winning Election on Share of Total Wages Public Employees Affiliated with Coalition Parties

\begin{tabular}{|c|c|c|c|c|c|c|}
\hline Winning Coalition & $\begin{array}{c}\text { Leading } \\
(1)\end{array}$ & $\begin{array}{c}\text { Supporting } \\
\text { (2) }\end{array}$ & $\begin{array}{c}\text { Leading } \\
(3)\end{array}$ & $\begin{array}{c}\text { Supporting } \\
\text { (4) }\end{array}$ & $\begin{array}{c}\text { Leading } \\
(5)\end{array}$ & $\begin{array}{c}\text { Supporting } \\
(6)\end{array}$ \\
\hline Relative Year: +1 & $\begin{array}{c}4.812 * * * \\
(0.056)\end{array}$ & $\begin{array}{c}1.207 * * * \\
(0.015)\end{array}$ & $\begin{array}{c}1.353 * * * \\
(0.067)\end{array}$ & $\begin{array}{c}0.165 * * * \\
(0.022)\end{array}$ & $\begin{array}{c}1.427 * * * \\
(0.065)\end{array}$ & $\begin{array}{c}0.286^{* * * *} \\
(0.019)\end{array}$ \\
\hline Relative Year: +2 & $\begin{array}{c}5.271 * * * \\
(0.063)\end{array}$ & $\begin{array}{c}1.395 * * * \\
(0.019)\end{array}$ & $\begin{array}{c}1.868^{* * *} \\
(0.077)\end{array}$ & $\begin{array}{c}0.235 * * * \\
(0.027)\end{array}$ & $\begin{array}{c}1.967 * * * \\
(0.075)\end{array}$ & $\begin{array}{c}0.382 * * * \\
(0.025)\end{array}$ \\
\hline Relative Year: +3 & $\begin{array}{c}6.320^{* * *} \\
(0.072)\end{array}$ & $\begin{array}{c}1.598 * * * \\
(0.021)\end{array}$ & $\begin{array}{c}2.721 * * * \\
(0.084)\end{array}$ & $\begin{array}{c}0.238 * * * \\
(0.028)\end{array}$ & $\begin{array}{c}2.821 * * * \\
(0.082)\end{array}$ & $\begin{array}{c}0.391 * * * \\
(0.025)\end{array}$ \\
\hline Relative Year: +4 & $\begin{array}{c}6.160 * * * \\
(0.071)\end{array}$ & $\begin{array}{c}1.529 * * * \\
(0.020)\end{array}$ & $\begin{array}{c}2.657 * * * \\
(0.083)\end{array}$ & $\begin{array}{c}0.227 * * * \\
(0.028)\end{array}$ & $\begin{array}{c}2.756^{* * *} \\
(0.081)\end{array}$ & $\begin{array}{c}0.378 * * * \\
(0.025)\end{array}$ \\
\hline Relative Year: +5 & $\begin{array}{c}3.858 * * * \\
(0.050)\end{array}$ & $\begin{array}{c}0.911 * * * \\
(0.015)\end{array}$ & $\begin{array}{c}1.093 * * * \\
(0.073)\end{array}$ & $\begin{array}{c}0.074 * * \\
(0.025)\end{array}$ & $\begin{array}{c}1.280 * * * \\
(0.072)\end{array}$ & $\begin{array}{c}0.207 * * * \\
(0.023)\end{array}$ \\
\hline Relative Year: +6 & $\begin{array}{c}3.855 * * * \\
(0.055)\end{array}$ & $\begin{array}{c}0.987 * * * \\
(0.019)\end{array}$ & $\begin{array}{c}0.917 * * * \\
(0.090)\end{array}$ & $\begin{array}{c}0.052 \\
(0.034)\end{array}$ & $\begin{array}{c}1.147^{* * * *} \\
(0.089)\end{array}$ & $\begin{array}{c}0.213 * * * \\
(0.031)\end{array}$ \\
\hline Relative Year: +7 & $\begin{array}{c}3.608 * * * \\
(0.054)\end{array}$ & $\begin{array}{c}0.921 * * * \\
(0.018)\end{array}$ & $\begin{array}{c}0.644 * * * \\
(0.088)\end{array}$ & $\begin{array}{l}-0.035 \\
(0.035)\end{array}$ & $\begin{array}{c}0.876^{* * *} \\
(0.086)\end{array}$ & $\begin{array}{c}0.132 * * * \\
(0.032)\end{array}$ \\
\hline Relative Year: +8 & $\begin{array}{c}3.390 * * * \\
(0.052)\end{array}$ & $\begin{array}{c}0.868 * * * \\
(0.017)\end{array}$ & $\begin{array}{c}0.525^{* * *} \\
(0.088)\end{array}$ & $\begin{array}{l}-0.059 \\
(0.032)\end{array}$ & $\begin{array}{c}0.757 * * * \\
(0.086)\end{array}$ & $\begin{array}{c}0.104 * * * \\
(0.029)\end{array}$ \\
\hline Relative Year: +9 & $\begin{array}{c}2.935 * * * \\
(0.047)\end{array}$ & $\begin{array}{c}0.528 * * * \\
(0.015)\end{array}$ & $\begin{array}{c}0.660^{* * *} \\
(0.080)\end{array}$ & $\begin{array}{l}-0.032 \\
(0.030)\end{array}$ & $\begin{array}{c}0.858 * * * \\
(0.079)\end{array}$ & $\begin{array}{c}0.129 * * * \\
(0.027)\end{array}$ \\
\hline Relative Year: +10 & $\begin{array}{c}3.026^{* * * *} \\
(0.054)\end{array}$ & $\begin{array}{c}0.646^{* * *} \\
(0.025)\end{array}$ & $\begin{array}{c}0.674 * * * \\
(0.103)\end{array}$ & $\begin{array}{c}0.050 \\
(0.050)\end{array}$ & $\begin{array}{c}0.836^{* * *} \\
(0.101)\end{array}$ & $\begin{array}{c}0.203 * * * \\
(0.045)\end{array}$ \\
\hline Relative Year: +11 & $\begin{array}{c}2.654 * * * \\
(0.052)\end{array}$ & $\begin{array}{c}0.554 * * * \\
(0.024)\end{array}$ & $\begin{array}{c}0.453^{* * *} \\
(0.099)\end{array}$ & $\begin{array}{c}0.065 \\
(0.049)\end{array}$ & $\begin{array}{c}0.615^{* * *} \\
(0.096)\end{array}$ & $\begin{array}{c}0.219 * * * \\
(0.045)\end{array}$ \\
\hline Relative Year: +12 & $\begin{array}{c}2.463^{* * * *} \\
(0.048)\end{array}$ & $\begin{array}{c}0.505 * * * \\
(0.024)\end{array}$ & $\begin{array}{c}0.373 * * * \\
(0.092)\end{array}$ & $\begin{array}{c}0.036 \\
(0.048) \\
\end{array}$ & $\begin{array}{c}0.534 * * * \\
(0.089)\end{array}$ & $\begin{array}{c}0.189 * * * \\
(0.044)\end{array}$ \\
\hline Vote Share & \multicolumn{2}{|c|}{$\mathrm{N}$} & \multicolumn{2}{|c|}{$\mathrm{Y}$} & \multicolumn{2}{|c|}{$\mathrm{Y}$} \\
\hline Leading/Supporting Party & \multicolumn{2}{|c|}{$\mathrm{N}$} & \multicolumn{2}{|c|}{$\mathrm{Y}$} & \multicolumn{2}{|c|}{$\mathrm{Y}$} \\
\hline Leading X Vote Share & \multicolumn{2}{|c|}{$\mathrm{N}$} & \multicolumn{2}{|c|}{$\mathrm{Y}$} & \multicolumn{2}{|c|}{$\mathrm{Y}$} \\
\hline City, Year, Party FE & \multicolumn{2}{|c|}{$\mathrm{N}$} & \multicolumn{2}{|c|}{$\mathrm{N}$} & \multicolumn{2}{|c|}{$\mathrm{Y}$} \\
\hline $\begin{array}{l}\text { R-sq. } \\
\text { No. Obs }\end{array}$ & \multicolumn{2}{|c|}{0.264} & \multicolumn{2}{|c|}{0.317} & 0.414 & $3,315,312$ \\
\hline
\end{tabular}


Table 7: Decomposition of Patronage Effects by Type of Employee

\begin{tabular}{|c|c|c|c|c|}
\hline & \multicolumn{4}{|c|}{ Decomposition } \\
\hline & (1) & (2) & (3) & (4) \\
\hline Employee status in previous year: & $\begin{array}{l}\text { No party, no } \\
\text { employment }\end{array}$ & $\begin{array}{l}\text { No party, } \\
\text { employed }\end{array}$ & $\begin{array}{l}\text { Party, no } \\
\text { employment }\end{array}$ & $\begin{array}{c}\text { Party, } \\
\text { employed }\end{array}$ \\
\hline \multicolumn{5}{|l|}{ Panel A. Patronage Share, Employees } \\
\hline Leading party rel. year: 1 & 0.039 & 0.018 & 0.508 & 0.433 \\
\hline Leading party rel. year: 2 & 0.09 & 0.064 & 0.568 & 0.276 \\
\hline Leading party rel. year: 3 & 0.171 & 0.126 & 0.386 & 0.315 \\
\hline Leading party rel. year: 4 & 0.233 & 0.139 & 0.398 & 0.228 \\
\hline Support party rel. year: 1 & 0.015 & 0.014 & 0.399 & 0.571 \\
\hline Support party rel. year: 2 & 0.062 & 0.054 & 0.516 & 0.366 \\
\hline Support party rel. year: 3 & 0.117 & 0.115 & 0.329 & 0.436 \\
\hline Support party rel. year: 4 & 0.176 & 0.183 & 0.392 & 0.247 \\
\hline \multicolumn{5}{|l|}{ Panel B. Patronage Share, Wages } \\
\hline Leading party rel. year: 1 & 0.063 & 0.045 & 0.591 & 0.301 \\
\hline Leading party rel. year: 2 & 0.161 & 0.091 & 0.747 & 0.000 \\
\hline Leading party rel. year: 3 & 0.229 & 0.163 & 0.379 & 0.227 \\
\hline Leading party rel. year: 4 & 0.33 & 0.168 & 0.406 & 0.094 \\
\hline Support party rel. year: 1 & 0.031 & 0.029 & 0.402 & 0.537 \\
\hline Support party rel. year: 2 & 0.108 & 0.089 & 0.675 & 0.127 \\
\hline Support party rel. year: 3 & 0.136 & 0.083 & 0.331 & 0.448 \\
\hline Support party rel. year: 4 & 0.274 & 0.176 & 0.462 & 0.086 \\
\hline
\end{tabular}


Table 8: Dynamic RD Effects by Type of Labor Contract, Type of Occupation and Administration Function - Effect on Share of Total Wages

\begin{tabular}{|c|c|c|c|c|}
\hline \multirow[b]{2}{*}{ Winning Coalition } & \multicolumn{2}{|c|}{ Bureaucratic } & \multicolumn{2}{|c|}{ Service Oriented } \\
\hline & $\begin{array}{l}\text { Leading } \\
\text { (1) }\end{array}$ & $\begin{array}{c}\text { Supporting } \\
\text { (2) }\end{array}$ & $\begin{array}{l}\text { Leading } \\
\text { (3) }\end{array}$ & $\begin{array}{c}\text { Supporting } \\
\text { (4) }\end{array}$ \\
\hline Relative Year: +1 & $\begin{array}{c}0.502 * * * \\
-0.031\end{array}$ & $\begin{array}{c}0.102 * * * \\
-0.01\end{array}$ & $\begin{array}{c}0.156 * * * \\
-0.035\end{array}$ & $\begin{array}{l}0.025^{*} \\
-0.012\end{array}$ \\
\hline Relative Year: +2 & $\begin{array}{c}0.734 * * * \\
-0.036\end{array}$ & $\begin{array}{c}0.144 * * * \\
-0.015\end{array}$ & $\begin{array}{c}0.402 * * * \\
-0.04\end{array}$ & $\begin{array}{c}0.067 * * * \\
-0.014\end{array}$ \\
\hline Relative Year: +3 & $\begin{array}{c}0.979 * * * \\
-0.038\end{array}$ & $\begin{array}{c}0.127 * * * \\
-0.013\end{array}$ & $\begin{array}{c}0.922 * * * \\
-0.045\end{array}$ & $\begin{array}{c}0.125^{* * *} \\
-0.016\end{array}$ \\
\hline Relative Year: +4 & $\begin{array}{c}0.944 * * * \\
-0.038\end{array}$ & $\begin{array}{c}0.112 * * * \\
-0.014\end{array}$ & $\begin{array}{c}0.959 * * * \\
-0.044\end{array}$ & $\begin{array}{c}0.146^{* * *} \\
-0.015\end{array}$ \\
\hline Relative Year: +5 & $\begin{array}{c}0.455^{* * *} \\
-0.036\end{array}$ & $\begin{array}{c}0.057^{* * *} \\
-0.011\end{array}$ & $\begin{array}{c}0.667 * * * \\
-0.04\end{array}$ & $\begin{array}{c}0.111^{* * *} \\
-0.015\end{array}$ \\
\hline Relative Year: +6 & $\begin{array}{c}0.421 * * * \\
-0.042\end{array}$ & $\begin{array}{c}0.057 * * * \\
-0.017\end{array}$ & $\begin{array}{c}0.614 * * * \\
-0.049\end{array}$ & $\begin{array}{c}0.125^{* * *} \\
-0.019\end{array}$ \\
\hline Relative Year: +7 & $\begin{array}{c}0.253 * * * \\
-0.04\end{array}$ & $\begin{array}{c}0.02 \\
-0.018\end{array}$ & $\begin{array}{c}0.520 * * * \\
-0.05\end{array}$ & $\begin{array}{c}0.094 * * * \\
-0.02\end{array}$ \\
\hline Relative Year: +8 & $\begin{array}{c}0.200^{* * *} \\
-0.042\end{array}$ & $\begin{array}{c}0.017 \\
-0.016\end{array}$ & $\begin{array}{c}0.437 * * * \\
-0.051\end{array}$ & $\begin{array}{c}0.073^{* * *} \\
-0.018\end{array}$ \\
\hline Relative Year: +9 & $\begin{array}{c}0.235^{* * *} \\
-0.038\end{array}$ & $\begin{array}{c}0.039^{* *} \\
-0.014\end{array}$ & $\begin{array}{c}0.514 * * * \\
-0.048\end{array}$ & $\begin{array}{c}0.079 * * * \\
-0.017\end{array}$ \\
\hline Relative Year: +10 & $\begin{array}{c}0.265^{* * *} \\
-0.051\end{array}$ & $\begin{array}{l}0.056^{*} \\
-0.026\end{array}$ & $\begin{array}{c}0.505^{* * *} \\
-0.061\end{array}$ & $\begin{array}{c}0.121^{* * *} \\
-0.025\end{array}$ \\
\hline Relative Year: +11 & $\begin{array}{c}0.198^{* * *} \\
-0.044\end{array}$ & $\begin{array}{c}0.080^{* * *} \\
-0.021\end{array}$ & $\begin{array}{c}0.389 * * * \\
-0.063\end{array}$ & $\begin{array}{c}0.100^{* * *} \\
-0.029\end{array}$ \\
\hline Relative Year: +12 & $\begin{array}{c}0.157 * * * \\
-0.042 \\
\end{array}$ & $\begin{array}{c}0.076^{* * *} \\
-0.022 \\
\end{array}$ & $\begin{array}{c}0.345^{* * *} \\
-0.055 \\
\end{array}$ & $\begin{array}{c}0.086^{* *} \\
-0.028 \\
\end{array}$ \\
\hline Vote Share & & $Y$ & & \\
\hline $\begin{array}{l}\text { Leading/Supporting Party } \\
\text { Leading X Vote } \\
\text { Share }\end{array}$ & & $Y$ & & \\
\hline City, Year, Party FE & & $I$ & & \\
\hline $\begin{array}{l}\text { R-sq. } \\
\text { No. Obs }\end{array}$ & & $\begin{array}{l}71 \\
5,312\end{array}$ & 3,3 & $\begin{array}{l}62 \\
, 312\end{array}$ \\
\hline
\end{tabular}


Table 9: Effect of Civil Servant Wage Share on Personnel Wage Share of Local Expenditures

\begin{tabular}{|c|c|c|c|c|}
\hline & \multicolumn{4}{|c|}{ Changes in Share of Expenditures with } \\
\hline & $\begin{array}{c}\text { Personnel } \\
(1)\end{array}$ & $\begin{array}{c}\text { Investments } \\
(2)\end{array}$ & $\begin{array}{l}\text { Affiliated Civil } \\
\text { Servants } \\
(3) \\
\end{array}$ & $\begin{array}{c}\text { Non-Affiliated } \\
\text { Civil Servants } \\
(4)\end{array}$ \\
\hline $\begin{array}{l}\text { Wage share of affiliates } \\
\text { instrumented by } \\
\text { patronage index }\end{array}$ & $\begin{array}{c}0.079 \\
(0.044)\end{array}$ & $\begin{array}{c}0.121 \\
(0.069)\end{array}$ & $\begin{array}{c}0.329 * * * \\
(0.021)\end{array}$ & $\begin{array}{c}-0.293 * * * \\
(0.052)\end{array}$ \\
\hline R-sq. & 0.233 & 0.228 & 0.215 & 0.210 \\
\hline State Fixed Effect & $\mathrm{Y}$ & $\mathrm{Y}$ & $\mathrm{Y}$ & $\mathrm{Y}$ \\
\hline Population control & $\mathrm{Y}$ & $\mathrm{Y}$ & $\mathrm{Y}$ & $\mathrm{Y}$ \\
\hline FINBRA control & $\mathrm{N}$ & $\mathrm{Y}$ & $\mathrm{Y}$ & $\mathrm{Y}$ \\
\hline No. Obs & 4,201 & 4,201 & 4,201 & 4,201 \\
\hline
\end{tabular}

Table 10: Effect of Civil Servant Wage Share on Service Oriented Wage Share of Local Expenditures

\begin{tabular}{|c|c|c|c|c|c|c|}
\hline & \multicolumn{6}{|c|}{ Changes in Share of Expenditures with } \\
\hline & $\begin{array}{l}\text { Teachers } \\
\quad \text { (all) }\end{array}$ & $\begin{array}{l}\text { Doctors } \\
\quad \text { (all) }\end{array}$ & $\begin{array}{l}\text { Teachers } \\
\text { (affiliated) }\end{array}$ & $\begin{array}{l}\text { Teachers (non- } \\
\text { affiliated) }\end{array}$ & $\begin{array}{c}\text { Doctors } \\
\text { (affiliated) }\end{array}$ & $\begin{array}{l}\text { Doctors (non- } \\
\text { affiliated) }\end{array}$ \\
\hline & (1) & $(2)$ & (3) & (4) & (5) & (6) \\
\hline $\begin{array}{l}\text { Wage share of } \\
\text { affiliates } \\
\text { instrumented by } \\
\text { patronage index }\end{array}$ & $\begin{array}{c}-0.094 * * * \\
(0.026)\end{array}$ & $\begin{array}{c}-0.043 * * * \\
(0.008)\end{array}$ & $\begin{array}{l}0.027 * * \\
(0.009)\end{array}$ & $\begin{array}{c}-0.121 * * * \\
(0.024)\end{array}$ & $\begin{array}{c}0.001 \\
(0.002)\end{array}$ & $\begin{array}{c}-0.044 * * * \\
(0.007)\end{array}$ \\
\hline R-sq & 0.229 & 0.004 & 0.382 & 0.172 & 0.043 & -0.020 \\
\hline State FE & $\mathrm{Y}$ & $\mathrm{Y}$ & $\mathrm{Y}$ & $\mathrm{Y}$ & $\mathrm{Y}$ & $\mathrm{Y}$ \\
\hline Pop control & $\mathrm{Y}$ & $\mathrm{Y}$ & $\mathrm{Y}$ & $\mathrm{Y}$ & $\mathrm{Y}$ & $\mathrm{Y}$ \\
\hline FINBRA control & $\mathrm{Y}$ & $\mathrm{Y}$ & $\mathrm{Y}$ & $\mathrm{Y}$ & $\mathrm{Y}$ & $\mathrm{Y}$ \\
\hline No. Obs & 4,201 & 4,201 & 4,201 & 4,201 & 4,201 & 4,201 \\
\hline \multicolumn{7}{|c|}{$\begin{array}{l}\text { Notes: This table presents the estimates of the effect of the 2012-1995 change in political occupation (share of wages going to affiliated employees), } \\
\text { instrumented by patronage index, on the change of composition of teachers and doctors employed by public governments in Brazilian cities. Column } \\
\text { (1), (3) and (4) show, respectively, the estimated effects on changes in share of expenditures with all teachers, affiliated teachers and non-affiliated } \\
\text { teachers. Column (2), (5) and (6) show, respectively, the estimated effects on changes in share of expenditures with all doctors, affiliated doctors and } \\
\text { non-affiliated doctors. Other controls include changes in city population and changes in total expenditures. Standard errors are clustered by state. }\end{array}$} \\
\hline
\end{tabular}


Table 11A: Effect of Civil Servant Wage Share on Local Education Outcomes

\begin{tabular}{|c|c|c|c|c|c|}
\hline & $\begin{array}{c}\% \text { with }>11 y \\
\text { of educ } \\
(1)\end{array}$ & $\begin{array}{c}\% \text { with }>8 y \\
\text { of educ } \\
(2)\end{array}$ & $\begin{array}{c}\% \text { with }>4 y \\
\text { of educ } \\
(3)\end{array}$ & $\begin{array}{c}\% \text { with }<4 y \\
\text { of educ } \\
(4)\end{array}$ & $\begin{array}{c}\% \text { literate } \\
(5)\end{array}$ \\
\hline $\begin{array}{l}\text { Wage share of } \\
\text { affiliates } \\
\text { instrumented by } \\
\text { patronage index }\end{array}$ & $\begin{array}{c}-0.376 * * * \\
(0.057)\end{array}$ & $\begin{array}{c}-0.116^{* *} \\
(0.038)\end{array}$ & $\begin{array}{l}-0.011 \\
(0.083)\end{array}$ & $\begin{array}{l}-0.086 \\
(0.066)\end{array}$ & $\begin{array}{l}-0.080 \\
(0.049)\end{array}$ \\
\hline R-sq & 0.107 & 0.189 & 0.673 & 0.647 & 0.632 \\
\hline State FE & $\mathrm{Y}$ & $\mathrm{Y}$ & $\mathrm{Y}$ & $\mathrm{Y}$ & $\mathrm{Y}$ \\
\hline Pop control & $\mathrm{Y}$ & Y & $\mathrm{Y}$ & Y & $\mathrm{Y}$ \\
\hline FINBRA control & $\mathrm{Y}$ & Y & $\mathrm{Y}$ & Y & $\mathrm{Y}$ \\
\hline No. Obs & 4,194 & 3,843 & 3,843 & 3,843 & 3,843 \\
\hline \multicolumn{6}{|c|}{$\begin{array}{l}\text { Notes: This table presents the estimates of the effect of the 2012-1995 change in political occupation (share of wages going } \\
\text { to affiliated employees), instrumented by patronage index, on the change of local education outcomes over the period } 1991- \\
2010 \text { in Brazilian cities. Column (1) shows the estimated effects on changes in the percentage of local population ages } 25 \text { and } \\
\text { above who have more the } 11 \text { years of schooling. The estimated effect on the percentage of local population ages } 15 \text { and above } \\
\text { who have more than } 4 \text { and } 8 \text { years of schooling, and less than } 4 \text { years of schooling are, respectively, in columns (2), (3) and } \\
\text { (4). Column (5) exhibits the estimated effect on adult literacy rate. Other controls include changes in city population and } \\
\text { changes in total expenditures. Standard errors are clustered by state. }\end{array}$} \\
\hline
\end{tabular}

Table 11B: Effect of Civil Servant Wage Share on Mortality Rates

\begin{tabular}{|c|c|c|c|c|}
\hline & $\begin{array}{l}\text { fetal } \\
\text { (1) }\end{array}$ & $\begin{array}{c}<1 \text { year } \\
(2)\end{array}$ & $\begin{array}{c}<4 \text { years } \\
(3)\end{array}$ & $\begin{array}{c}4<\text { years }<74 \\
\text { (4) }\end{array}$ \\
\hline $\begin{array}{l}\text { Wage share of } \\
\text { affiliates } \\
\text { instrumented by } \\
\text { patronage index }\end{array}$ & $\begin{array}{c}0.393 * * * \\
(0.108)\end{array}$ & $\begin{array}{c}0.801 * * * \\
(0.186)\end{array}$ & $\begin{array}{c}1.035 * * * \\
(0.218)\end{array}$ & $\begin{array}{l}2.033 * \\
(0.834)\end{array}$ \\
\hline R-sq & 0.118 & 0.112 & 0.104 & 0.214 \\
\hline State FE & $\mathrm{Y}$ & $\mathrm{Y}$ & $\mathrm{Y}$ & Y \\
\hline Pop control & $\mathrm{Y}$ & $\mathrm{Y}$ & $\mathrm{Y}$ & $\mathrm{Y}$ \\
\hline FINBRA control & $\mathrm{Y}$ & $\mathrm{Y}$ & $\mathrm{Y}$ & $\mathrm{Y}$ \\
\hline No. Obs & 4,201 & 4,201 & 4,201 & 4,164 \\
\hline \multicolumn{5}{|c|}{$\begin{array}{l}\text { Notes: This table presents the estimates of the effect of the 2012-1995 change in political occupation (share } \\
\text { of wages going to affiliated employees), instrumented by patronage index, on the change of local mortality } \\
\text { rates (per 100,000 inhabitants) over the period } 1996 \text { and } 2013 \text { in Brazilian cities. Column (1) shows the } \\
\text { estimated effects on changes in the fetal mortality. The estimated effect on infant mortality (before } 1 \text { year) } \\
\text { and on mortality of individuals below age } 4 \text { are, respectively, in columns (2) and (3). Column (4) exhibits } \\
\text { the estimated effect on mortality rates of individuals between ages } 14 \text { and } 74 \text {. Other controls include changes } \\
\text { in city population and changes in total expenditures. Standard errors are clustered by state. }\end{array}$} \\
\hline
\end{tabular}

